\title{
1 Genesis of natural hydraulic fractures as an indicator of basin 2 inversion
}

3 Qingfeng Meng, John Hooker, and Joe Cartwright

4 Department of Earth Sciences, University of Oxford, South Parks Road, Oxford, OX1 3AN, UK

5 meng.qingfeng@hotmail.com

\section{ABSTRACT}

7 Satin spar (fibrous gypsum) veins, which occur in evaporite basins worldwide, provide

8 significant insights into host rock deformation and fluid flow, although the genetic mechanism

9 remains obscure. Satin spar veins in the red marls of the Triassic Mercia Mudstone of the Bristol

10 Channel Basin were characterized in the context of regional and local setting. The vein network

11 in the Keuper Marl (lower Mercia) exhibits a lack of systematic cross-cutting between three

12 distinct vein sets. Two sets of veins are observed in the overlying Tea Green Marl, with one set

13 clearly crossing the other. The gypsum veins commonly contain a blocky median zone of

14 multiple thin bands of host-rock inclusions and alabastrine gypsum crystals, exhibiting crack-

15 seal patterns. Fibrous zones on either side of the median zone consist of pure parallel-aligned

16 gypsum fibres that are oblique to vein walls, indicating a hybrid shear-extensional mode of vein

17 widening. Veins developed within reverse-reactivated faults contain fibre lineations in the median zones and also on vein surfaces, suggesting a minimum of two phases of fault slip. The

19 veins are interpreted to have formed as a result of overpressure in the low-permeability 
21 Growth of gypsum fibres commenced when the initial fractures were completely sealed. The

22 timing of vein formation is suggested to be Miocene, based on cross-cutting relationships with

23 folds formed during the latest phase of basin inversion. Because the fractures initiated in

24 response to fluid overpressures, they provide a useful analog to subsurface hydraulic fracture

25 systems in low-permeability rocks subjected to tectonic compression. The fibrous widening of

26 the veins post-dates their initiation and led to continued propagation and increased connectivity.

27 Key words: hydraulic fracture; mudstone; crack-seal; antitaxial vein; basin inversion; 28 overpressure

\section{1. Introduction}

30 Gypsum $\left(\mathrm{CaSO}_{4} \cdot 2 \mathrm{H}_{2} \mathrm{O}\right)$ occurs in nature in a variety of polycrystalline forms (Machel, 1985).

31 Satin spar is a fibrous variety of needle-like gypsum crystals filling fractures (Gustavson et al., 32 1994). Satin spar veins, consisting of numerous parallel-aligned gypsum fibres, are commonly

33 present in evaporite beds of sedimentary basins worldwide (Gustavson et al., 1994; Warren, 2006;

34 Cobbold et al., 2013). The veins mainly appear in Triassic and Neogene strata, which are times

35 of vast evaporite production under a warm and dry climate (Cobbold et al., 2013). The host rocks

36 are mostly mudrocks and evaporites, or less commonly carbonates (Nichols, 2009; Cobbold et al.,

37 2013). Recently, satin spar veins have been found on Mars, which indicates aqueous fluid

38 activities in the hosts (Squyres et al., 2012; Arvidson et al., 2014; Nachon et al., 2014).

39 Satin spar veins have received considerable attention because their geometry and texture can 40 provide information of the paleostress states, host rock deformations, and paleo-hydrological 41 systems of their host rocks (Cosgrove, 1993; Passchier and Trouw, 1996; Bons, 2000; Bons et al., 42 2012; Cobbold et al., 2013; Moragas et al., 2013). The similarities of satin spar veins in many 
43 evaporite basins indicate that they could share a common origin (Gustavson et al., 1994).

44 Although it is generally acknowledged that the formation of fibrous veins is related to fracture

45 mechanics (Bons et al., 2012), no consensus exists about their genesis. Gustavson et al. (1994)

46 proposed that extension fractures could be created by subsidence over areas of halite dissolution,

47 followed by precipitation of satin spar crystals in the fractures. Tabakh et al. (1998) argued that

48 satin spar veins are initiated from overlying sediment unloading and exhumation, which not only

49 favours the generation of sub-horizontal fractures, but also the dissolution of evaporites and

50 subsequent remobilization. Considering the predominant low-permeability host rocks and

51 sulphate-rich fluid movement, more researchers suggested that satin spar veins formed as natural

52 hydraulic fractures that are cemented by gypsum from gypsum-saturated brines (Cosgrove, 2001;

53 Philipp, 2008). The origin of overpressure is mainly attributed to tectonic compression by

54 Cosgrove (2001), whereas Testa and Lugli (2000) and Philipp (2008) suggested that

55 overpressure is more likely to result from anhydrite hydration and the associated solid-

56 volumetric increase. However, Machel (1985) did not support the idea of anhydrite-gypsum

57 transition in the host rocks as a prerequisite for the formation of satin spar veins. Instead, the

58 author interpreted the veins to be tensile fractures either due to lateral tectonic compression,

59 hydraulic overpressure, or a combination of the two factors. In a recent study, Rustichelli et al.

60 (2016) subdivided satin spar veins into two types: (a) fault-related fractures in fault damage

61 zones; and (b) bedding-parallel fractures formed by overpressure, which were later cemented by

62 gypsum through diffusion.

63 This paper presents the field and petrographic study of the satin spar veins in the Triassic Mercia

64 Mudstone of the Bristol Channel Basin that are exposed along the Somerset coast. A previous

65 study of this area by Cosgrove (2001) suggested that the satin spar veins in the Mercia Mudstone 
formed as natural hydraulic fractures during Cenozoic basin inversion. Fluid overpressure, which

67 resulted from N-S tectonic compression, opened tensile fractures vertically against the minimum

68 principal stress. Cosgrove interpreted that gypsum played a role only in the preservation of the

69 veins, preventing their closure after overpressures ceased. Philipp (2008) supported the

70 interpretation that the satin spar veins formed as hydraulic fractures, but attributed the

71 overpressure to the hydration of anhydrite on the basis of the stratigraphic distribution of veins,

72 ruptured nodules, and gypsum-lined faults. This paper presents additional observations to expand

73 those provided in previous studies, particularly as regards the geometry and texture of the fibrous

74 veins, which, we argue, imply a two-stage development. The aims of this paper are (1) to analyze

75 the timing constraints of the satin spar veins in the marls; (2) to examine the mechanism of vein

76 generation and its expression in vein microtextures; (3) to obtain a better understanding of the

77 relationship between fault reactivation, fluid migration, pore pressure and the associated

78 mineralization; and (4) to derive a general model for the formation of satin spar veins in low-

79 permeability mudstones. The satin spar vein system in the Mercia Mudstone presented in this

80 study constitutes an analogue to subsurface hydraulic fracture networks in mudstone.

\section{$81 \quad 2 . \quad$ Basinal context}

82 The study area is located on the southern margin of the Bristol Channel Basin (BCB) (Fig. 1).

83 The approximately E-W trending BCB extends from Wales to Somerset, $155 \mathrm{~km} \mathrm{E-W}$ and $30 \mathrm{~km}$

84 N-S (Nemčok et al., 1995). The BCB was initiated in the early Permian to Triassic as an

85 extensional basin developed around the south of England due to the breakup of the Pangaea

86 (Kamerling, 1979; Van Hoorn, 1987; Brooks et al., 1988; Roberts, 1989; Coward, 1995). The

87 BCB experienced extension and subsidence through the Triassic and Jurassic (Miliorizos and

88 Ruffell, 1998), which led to the development of approximately E-W trending and southward- 
89 dipping normal faults (Donato, 1988; Peacock and Sanderson, 1999). These basin-controlling 90 normal faults were detached on a major Variscan thrust fault at depth that was reactivated and 91 controlled the location and orientation of the normal faults (Donato, 1988; Peacock and 92 Sanderson, 1991, 1994; Ruffell and Coward, 1992).

93 The main basin developed as a half graben bounded by the Bristol Channel Fault Zone 94 (Kamerling, 1979; Brooks et al., 1988; Glen et al., 2005). During the Late Cretaceous to the 95 Early Cenozoic, inversion occurred in the $\mathrm{BCB}$ as the result of N-S contraction caused by the 96 Alpine orogeny (Van Hoorn, 1987; Peacock and Sanderson, 1992). The evidence for this phase 97 of contraction comes from seismic profiles, field exposures of reverse-reactivated normal faults 98 and strike-slip faults conjugate about a N-S orientation (Peacock and Sanderson, 1992, 1999). 99 Most reverse-reactivated normal faults retain finite normal displacements; however, some faults 100 changed into reverse faults (Peacock and Sanderson, 1992; Dart et al., 1995).

101 During the Permian and Triassic, the interplay of sea level change, extension-driven subsidence 102 and climatic fluctuations significantly affected the sedimentation of the BCB (Ruffell and 103 Shelton, 1999). Sediments deposited were typical of an arid environment including lacustrine red 104 sedimentary rocks (Cosgrove, 2001), including conglomerate, sandstone, siltstone and mudstone 105 (Whittaker and Green, 1983) (Fig. 2). During the Anisian, the Mercia Mudstone was deposited in 106 subaqueous, hypersaline and evaporitic mudflats that replaced the southward retreating fluvial 107 environment (Tucker, 1977; Dart et al., 1995). The Mercia Mudstone mainly consists of reddish108 brown, less commonly green and grey, mudstones and marls with beds of halite in Somerset 109 (Whittaker and Green, 1983; Howard et al., 2008). Subsequent transgression in the Late Triassic to Early Jurassic was accompanied by the deposition of grey to black marine mudstone of the 
111 Lower Penarth Group and interbedded mudstones and thin limestones of the Blue Lias Group

112 (Whittaker and Green, 1983; Howard et al., 2008).

113 3. Methods

114 Field observation along the cliffs was focused on vein shape, orientation, intersection, 115 composition and texture. Vein orientation data were collected from nine randomly-selected sites 116 using the 2D circular window method (one window per site), which could help comprise larger 117 data sets and reduce sampling bias compared to linear scanline method (Mauldon et al., 2001). 118 We gathered orientations of all veins within circular surfaces with a diameter of $1 \mathrm{~m}$. Vein 119 orientations were plotted by means of stereonet projection as great circles using Stereonet 9 120 software (Fig. 1A). Representative veins and their host rocks were sampled and cut into thin 121 sections. Vein samples were deemed to be representative for petrographic analysis based on the 122 fact that the veins exhibit a median suture of host rock inclusions with a finite width, and two 123 outer zones of fibrous gypsum. The planes of thin sections are perpendicular to the plunge 124 direction of fibres in veins, so that the true relative angle between fibres and vein walls could be 125 observed. Microtextures of satin spar veins were characterized to provide clues for vein 126 generation and cementation processes. Cross-cutting relationships between different sets of veins 127 and between veins and other structures (faults, folds and sandstone dykes) were recorded to yield 128 relative timing of the structures

\section{$129 \quad$ 4. Local setting}

130 The study area is located in Warren Bay in the Watchet area, Somerset (Fig. 1). The coastal cliffs 131 near Watchet mainly expose the Triassic strata of the Mercia Mudstone Group and the Lower 132 Jurassic Blue Lias Formation (Figs 1, 2). The Mercia Mudstone is subdivided into the Keuper 
133 Marl Formation and the Tea Green Marl Formation. The Keuper Marl is the oldest stratigraphic

134 unit exposed, mainly consisting of red and brown featureless marls, occasionally green or grey

135 siltstones, and few fossils. The Tea Green Marl Formation (TGM), also known as the Blue

136 Anchor Formation, overlies the Keuper Marl and comprises laminated green-grey, red-brown

137 dolomitic silty mudstone, and grey, black, green, and yellowish-grey dolostones.

138 Nodular gypsum is observed in multiple horizons in both the Keuper Marl and the TGM (Fig.

139 3A-B) where nodules are suggested to be generated as syndepositional evaporites in the capillary

140 and upper phreatic zones beneath sabkha surface (Nichols, 2009). The depositional evaporites

141 will experience a 'gypsum-anhydrite-gypsum cycle' (Murray, 1964), i.e. dehydrate to anhydrite

142 when burial depth exceeds several hundred meters, and rehydrate to gypsum when it comes in

143 contact with the low salinity, low-temperature pore waters on uplift to the telogenetic zone.

144 Thus, diagenetically regenerated gypsum present as gypsum nodules and veins is regarded as

145 secondary gypsum (Tucker, 2009).

146 Twelve sandstone dykes are observed in the Keuper Marl, mostly NNW-SSE striking with

147 medium to high angle dips $\left(37^{\circ}-84^{\circ}\right)$ (Fig. 3) (Table 1). The sandstone dykes are composed of

148 gypsum cemented, coarse sandstones that are compositionally identical to a sandstone body at

149 the base of the Keuper Marl. Thus, the sandstone body is interpreted to have acted as the source

150 of sand for the sandstone dykes. The dykes exhibit variable aperture ranging between 0.8-14.6

$151 \mathrm{~cm}$. The traces of the dykes are mostly curvy, which have been interpreted to be buckled

152 hydraulic fractures formed during early burial and diagenesis (Cosgrove, 2001). A normal fault

153 is observed to offset a sub-vertical sandstone dyke with a throw of $0.8 \mathrm{~m}$, whereas the correlative

154 nodular horizons indicate a maximum fault throw of $2.1 \mathrm{~m}$ (Fig. 3A). Some dykes contain dense

155 gypsum veins, one of which includes a red host rock fragment trapped within the dyke (Fig. 3C- 
D). This displacement difference suggests that the sandstone dyke was intruded later in the

157 displacement history of the normal fault.

158 Numerous normal faults transect the outcrop of the Mercia Mudstone (Figs 1, 3A). These faults 159 mostly strike E-W and NW-SE and dip at moderate to high angles $\left(37^{\circ}-83^{\circ}\right)$ (see supplementary 160 material, Table S2). Three reverse faults cut the Mercia Mudstone in the study area with 161 displacement ranging from 0.15 to $1.1 \mathrm{~m}$. Such faults are interpreted to be normal faults that were 162 reactivated to accommodate the basin shortening (Kelly et al., 1999). The Blue Lias and the 163 Mercia Mudstone outcrop in a horst that is bounded to the South by the E-W striking Helwell 164 Bay Fault (Figs 1B, 4A). The horst is cut by the NW-SE striking Watchet Fault that transects the 165 Mesozoic basin margin structures and possibly initiated as a Variscan structure (Holloway and 166 Chadwick, 1986).

167 Buttress anticlines are observed in the hanging wall of reactivated normal faults (Fig. 4A) as the 168 result of accommodation of basin shortening during Alpine compression and flexural flow with 169 bed-parallel slip (Nemčok et al., 1995; Engelder and Peacock, 2001). The anticlines verge 170 towards the horst and locally exhibit overturned forelimbs. The fold axes mainly strike NNW171 SSE. Axial surfaces may dip as low as $20^{\circ}$. Intense buttressing occurs in the hangingwall of the 172 Helwell Bay Fault to the east of the Watchet Fault, where complex parasitic anticlines and 173 synclines develop around the crest. The folds are cut by numerous minor faults which are sub174 parallel to the main faults. Detachment folds are observed in the Lower Lias strata of the horst, 175 whose fold axes trend approximately E-W (Fig. 4B). The underlying evaporite beds of the TGM 176 contain abundant nodular gypsum, and act as the décollement. The beds in the folds dip gently 177 north, which increases sharply to be sub-vertical to the south. 


\section{$178 \quad$ 5. Vein pattern}

179 The red marls of the Keuper Marl expose dense networks of satin spar veins (Fig. 5A-D). The 180 veins exhibit three preferred orientations, including the NW-SE striking and north dipping veins 181 (K-1), E-W striking and south dipping veins (K-2), and sub-horizontal veins (K-3) (Figs 1, 5C).

182 The veins of set $\mathrm{K}-1$, dipping northward at $60^{\circ}$, are parallel to the E-W striking, basin-bounding 183 normal faults along the southern margin of the basin. Those veins have been interpreted to be 184 fault-controlled tectonic fractures (Cosgrove, 2001). The veins of set K-2 are parallel to the 185 Helwell Bay Fault and many other normal faults exposed in the Warren Bay area. The sub186 horizontal veins of set K-3 are sub-parallel to bedding planes.

187 Different veins in the Keuper Marl range from millimeters to tens of meters in length, and 188 millimeters to $17 \mathrm{~cm}$ in aperture. The veins occur either as isolated individuals or as groups of 189 closely-spaced veins with frequent intersections with adjacent inclined veins (Figs 5B, 5D). 190 Small veins commonly exhibit tapering tips that pinch out in the marls, or curve towards 191 neighboring veins. Sub-horizontal veins frequently occur as sets of en echelon veins (Fig. 6). The 192 tips of neighboring veins commonly curve towards the neighboring vein and coalesce with them, 193 hence trapping host rock fragments between vein tips. Similar features have also been observed 194 by Virgo et al. (2014). Some sub-horizontal veins contain multiple parallel host-rock fragments, 195 which are oblique to vein walls (Fig. 6D-H). Such veins are interpreted to result from 196 coalescence of en echelon veins during lateral propagation.

197 The gypsum veins in the TGM exhibit distinctly different patterns from those in the Keuper Marl 198 (Fig. 5E-F). The veins are more consistently oriented as two main sets, comprising an E-W 199 striking, sub-vertical set (T-1) and a bedding-parallel set (T-2). Veins of set T-1 are pinkish-red 
200 and quite evenly spaced (Fig. 5E). They commonly transect more than a single bed, with a height 201 ranging from millimeters to approximately $2 \mathrm{~m}$. Some of the pink veins exhibit sigmoidal shapes

202 in the flat-lying beds of dolomites (Fig. 5F). The axial surfaces of those folds are approximately 203 E-W striking. The curved veins are intact without signs of modifications. Veins of set T-2 are 204 mainly concentrated in dark marls. These veins are white and bedding-parallel. White satin spar 205 veins are also observed in the folds (Fig. 4A). The veins are predominately wavy. They may also 206 exhibit a general sub-horizontal orientation and cross-cut multiple folded layers. This geometry 207 indicates that the white veins postdate the folding of the host strata.

\section{$208 \quad 6 . \quad$ Texture and composition}

209 The satin spar veins are mainly filled with fibrous gypsum crystals that are oblique to vein walls 210 (Fig. 7A), indicating a shear component. The crystals are parallel-aligned and needle-like. Single 211 fibres commonly exhibit an optical continuity, and remain constant in width (Fig. 7C-D). Fibrous 212 gypsum crystals commonly exhibit high aspect ratios (up to 120). However, the values of aspect 213 ratios vary in different veins, which is reflected in vein texture. Veins comprising crystals with 214 aspect ratios $<10$ often exhibit an elongate-fibrous texture (Bons et al., 2012). Growth 215 competition between crystals frequently occurs, with some crystals that overgrow others.

216 Most gypsum veins, especially the sub-horizontal veins, exhibit a thin band of median zone 217 enclosed by upper and lower gypsum fibres (Fig. 7B-F). The median zone is not strictly located 218 within the central part of the gypsum veins, and can be closer to either the upper or the lower 219 vein walls (Fig. 7B, 7E). The median zone is mainly composed of host-rock inclusions. Locally, 220 the median zone often contains large lenticular host-rock fragments with the long axes aligned 221 sub-parallel to vein walls. Thin sections of satin spar veins reveal that the median zones have a 
222 finite width. The median zone in single vein consists of multiple bands of wall-parallel host rock

223 inclusions and alabastrine gypsum, exhibiting an overall blocky texture (Fig. 7C-E). The gypsum

224 crystals are irregularly shaped and interlocked with neighbours. In veins with median zones,

225 fibres on the same side of the median zone share similar geometries and sizes, but exhibit

226 differences from those on the different side. Interestingly, fibres on one side commonly exhibit

227 smoother crystal boundaries than those on the other side. Overgrowth geometries frequently

228 occurs between crystals on the less-fibrous side.

229 Some satin spar veins do not contain median zones, and are fully filled with gypsum fibres that

230 continue from one wall to the other. Elongate-fibrous gypsum veins rarely have median zones.

231 Those veins are mainly composed of elongate-blocky crystals with long axes sub-orthogonal to

232 vein walls.

\section{$233 \quad 7 . \quad$ Vein branching}

234 The satin spar veins commonly split into two or three branches during widening (Fig. 8). The 235 sum of aperture of the branches is similar to the original vein. One of the branches is often 236 parallel to the parent vein, and the other branch deviates from the original direction. The median 237 zone is only retained in one branch, and is not affected by vein branching and the change in vein 238 aperture. Interestingly, the bifurcations are not located in the median zone: they are in either the 239 upper or the lower fibrous zones in the veins (Fig. 8A-D). The apparent angles between the 240 branches and the parent veins varies from several degrees to almost ninety degrees. 


\section{$241 \quad$ 8. Cross-cutting relationships}

$242 \quad$ 8.1. Differently Oriented Veins

243 Intersection of differently oriented gypsum veins is commonly observed in the red marls of the

244 Keuper Marl, but no systematic cross-cutting of one set by another occurs. Although the 245 intersecting veins are commonly seen as ' $\mathrm{x}$ ' shaped geometries on cliff faces, they do not cross246 cut one another (Fig. 9A-C). A representative scenario that can be misinterpreted as vein cross247 cutting is shown in Fig. 9A. Coalescence occurs between sets K-1 and K-3. Vein $a$ and $c$ form an 248 intact vein that exhibit smooth transitions at the nodes where vein-dip changes, so do vein $b$ and $249 d$. Hence, vein $a$ and $b$ are unlikely to have formed as a single vein that was later modified. This 250 interpretation is evident from the consistently oriented fibres in the veins, which are interpreted 251 to have filled the horizontal and steep segments synchronously.

252 Fig. 9B shows intersections of three curved veins. Coalescence occurs between vein $a$ and $b$, and 253 also vein $a$ and $c$. Vein $b$ propagated towards the plane of vein $a$, which is indicated by the 254 tapering tip to the left in the figure. Vein $c$ is strongly curved, and it coalesces with vein $a$ for 2 $255 \mathrm{~cm}$ where the vein exhibits the maximum curvature. The coalescence of those veins results in a 256 complex vein network.

257 Sub-horizontal veins, including branches, do not cross-cut steeply dipping veins (Fig. 9C). The 258 tapering tips of sub-horizontal veins either coalesce with the steep veins or curve to follow their 259 planes. Some steep veins are observed to occur as steps that link two adjacent horizontal veins 260 (Fig. 9D). All veins share the same fibre orientations. 
261 Some inclined veins are rooted in sub-horizontal veins, with the maximum aperture located in

262 the bifurcation (Fig. 9E). The aperture of the inclined veins gradually decreases towards the host

263 rock. The tips of such veins either pinch out or coalesce with adjacent sub-horizontal veins.

264 Thus, coalescence commonly occurs between differently oriented gypsum veins instead of cross-

265 cutting where they intersect, which is especially common between veins of sets K-1 and K-3. In

266 the Tea Green Marl, the red veins of set T-1 are clearly cross-cut by the bedding-parallel white

267 veins of set T-2 with little offset (Fig. 5E).

\section{$268 \quad$ 8.2. Timing of Veins vs. Faults}

269 The informal term 'fault vein' is used here to refer to veins that develop in a fault-parallel 270 geometry within the fault zones of normal and reverse faults. Fault veins are observed to cross-

271 cut sub-horizontal gypsum veins in two reactivated reverse faults, including the Helwell Bay

272 Fault. The stratigraphy can be correlated from the hangingwalls to the footwalls of the two faults

273 using the groups of nodular gypsum horizons and this correlation allows the recognition of

274 offsets by faults of laterally extensive gypsum veins that share the same aperture, color and 275 internal texture. Fig. 10A shows two closely spaced, horizontal veins offset by the paler fault 276 vein with a fault throw of $92 \mathrm{~cm}$. Fault veins are also observed to cross-cut veins in the host rock 277 flanking the Helwell Bay Fault (Fig. 11A). The offset of the sub-horizontal white vein in the 278 hangingwall and the footwall suggests a reverse motion with a throw of $12 \mathrm{~cm}$. The needle-like 279 fibres as mineral lineation are interpreted to mark the direction of dip slip.

280 In the majority of example faults, horizontal veins in the host rock are not cross-cut by faults, 281 and instead the gypsum veins are seen to curve to follow the attitude of the fault planes (Fig. 
282 11D). It is interpreted that such veins progressively propagated towards the faults from the

283 adjacent areas and subsequently exploited the walls of fault veins as weak planes.

\section{$284 \quad$ 8.3. Timing of Veins vs. Folds}

285 The gypsum veins in the intensively folded layers of the Blue Anchor Formation are commonly 286 wavy, but their general orientations are sub-horizontal or slightly inclined. The veins frequently 287 cut across the inclined beds regardless of the position and curvature of the folded layers (Figs $2884 \mathrm{~A}, 9 \mathrm{H})$. Some veins have both sub-horizontal segments that cross-cut inclined beds, and also 289 inclined segments that deviate from the horizontal direction to follow the bedding, often 290 developing a wavy geometry. These wavy veins are observed to occur within beds of dark grey 291 marls that are often tightly folded. Importantly, the fibre direction in these veins is consistently 292 sub-vertical. If the wavy veins were folded with their host strata, we should instead observe a 293 systematic rotation of the fibre directions across the folded layers. Hence, it can be concluded 294 that vein formation postdated folding.

\section{8.4. Timing of Veins vs. Sandstone Dykes}

296 The sandstone dykes are considered as early-formed hydraulic fractures, based on their folded 297 geometry. This timing is interpreted to result from post-intrusion compaction of the host 298 mudstones (Cosgrove, 2001). The source sands must have been uncemented at the time of 299 intrusion (Cartwright, 2010), and therefore, fluidized during early burial at a time when fluid 300 overpressure was achieved, and when the differential stress was less than four times of the tensile 301 strength of the marls (Cosgrove, 2001). 
302 Additional evidence for the early timing of sandstone dykes is found from a normal fault that is

303 observed to cross-cut a sub-vertical dyke (Fig. 3A). The intrusion of the dyke is interpreted to

304 have occurred during the active period of the normal fault because the normal displacement of

305 the dyke is less than that of the nodular gypsum horizons that occur at the same location.

306 The sub-horizontal gypsum veins are invariably seen to cross-cut the sandstone dykes (Fig. 3).

307 Some gypsum veins curve to follow the dyke walls instead of cross-cutting them when they 308 encounter the sub-vertical dykes (Fig. 3C-D). Hence, the sandstone dykes are interpreted to 309 predate the gypsum veins.

\section{$310 \quad 9 . \quad$ Fault veins}

311 All exposed faults of the Mercia Mudstone are cemented by gypsum (Figs 10-13) (Table S2).

312 The E-W striking faults commonly expose slabs of white fault veins dipping north. The vein 313 width varies from less than one centimetre to $16.8 \mathrm{~cm}$. The median zones of the fault veins 314 contain a large amount of host-rock inclusions and impure gypsum masses (Fig. 12A-B). 315 Similarly to the satin spar veins in the rock matrix, the fault veins also contain two outer fibrous 316 parts that are rather pure in composition (Fig. 12B-C).

317 Most faults exposed in the region are in net extension, whereas some faults show kinematic 318 evidence for reverse reactivation (also see Glen et al., 2005). Fig. 10 shows a fault (F5) with a 319 reverse displacement, and contains a $6 \mathrm{~cm}$ thick fault vein that exhibit a fibrous texture, and 320 cross-cuts the horizontal gypsum veins in the bulk rock as a rare example of true cross-cutting. 321 Importantly, lineations are observed on vein surfaces (Fig. 10B, 10D), which exhibit a sub322 parallel direction to the fault plane. Those lineations are also parallel to striations on the surfaces 323 of fault wall rocks (Fig. 10B-C). It is interpreted that the lineations are parallel to the sense of 
324 slip. Depressions that are filled with centimetre-scale host rock fragments are observed on fault 325 vein surfaces (Fig. 10D). Those rock fragments lie ahead of numerous fibres that exhibit a 326 greater relief than the fragments, resulting in point asperities on vein surfaces. The fibre fronts 327 also commonly exhibit irregular traces and varied surface reliefs, which are possible slickenside 328 steps or the result of weathering.

329 Fig. 13 shows another reverse fault (F9) that contains a $4 \mathrm{~cm}$ thick gypsum fault vein. The fault 330 vein consists of lineations in the median zone that lie parallel to the fault plane, and two outer 331 fibrous parts. These fibres are sigmoidal-shaped, with the plunge gradually increasing to sub332 normal towards vein walls (Fig. 13B). Lineations are observed on vein surfaces (Fig. 13C), 333 which resemble those in the fault shown in Fig. 10D. The lineation front exhibits a crescent334 shaped trace, which has a greater relief than the vein surface ahead and is interpreted as a 335 slickenside step. Hence, the reverse slip of this fault is interpreted to be parallel to lineations on 336 fault vein surfaces.

337 The gypsum cements developed in the fault zone of the Helwell Bay Fault appear as straight 338 lineations lying within fault planes (Fig. 11). Those lineations are needle-like and coarser than 339 those in the satin spar veins in the host rock (Fig. 11B). The fault vein offsets sub-horizontal 340 veins in the marls (Fig. 11A), leaving fibre-parallel slickenlines on the sections of transected 341 veins in the marls (Fig. 11C). Hence, the lineations in the fault vein are interpreted to form 342 during the slip of the fault, which postdate the development of satin spar veins in the marls. Due 343 to the severe weathering of the fault vein and the marls, it is difficult to obtain additional 344 information of the sense of fault slip during the formation of the fibre lineations. However, 345 according to the reverse displacement of the horizontal satin spar vein, it is interpreted that the 346 lineations are associated with a reverse dip-slip of the Helwell Bay Fault. Such lineations in the 
347 fault veins have formed either by means of syn-kinematic recrystallization or 348 dissolution/precipitation (de Meer and Spiers, 1995, 1997; Fossen, 2010) that reshaped the 349 gypsum crystals on vein surfaces in the direction of fault slip.

350 Based on the observations above, fault veins are interpreted to record at least two increments of 351 displacement for faults in the study area (Fig. 14). During the first reverse reactivation of faults 352 due to tectonic compression, lineations were produced on fault planes and aligned parallel to the 353 fault slip direction. Such lineations are especially rich in the jogs that resulted from the asperities 354 of fault planes. Those straight lineations serve as the median zone for the final fault veins. Then 355 gypsum fibres start to grow towards vein walls during inactive periods of the faults. Finally, 356 another phase of fault reverse reactivation commenced, with fibre lineations generated on vein 357 surfaces that recorded the fault slip.

\section{Discussion}

\subsection{Vein initiation by hydraulic fracturing}

Satin spar veins in mudrocks have been suggested to form as hydraulic fractures (Shearman et al., 1972; Cosgrove, 1995, 2001) for the following reasons: (1) the formation of open-mode

362 fractures relies on the fluid pressure to assist in pushing apart the wall rocks against the total rock pressure (Mandl, 2005); and (2) a vein fill of calcium sulphate requires the precipitation of gypsum from sulphate-rich fluids. The N-S tectonic compression during basin inversion, which

365 is evident from fault reactivation and associated tight folding in the Watchet area (Figs 4, 11, 13), could have significantly contributed to the buildup of overpressure (c.f. Cosgrove, 2001). Due to

367 the extremely low bulk permeability of the marls (Seedhouse and Racey, 1997), a pervasive 368 increase of pore pressure $\Delta p$ could occur because fluid cannot expel fast enough (Luo et al., 
Cracking preferentially occurs at vein-wall interfaces due to the low cohesion (Gale and Holder,

2007; Couzens-Schultz and Azbel, 2014 ). The rise of pore pressure $\Delta p$ reduces the effective stress to the point where tensile failure occurs resulting in hydraulic fractures (Mandl, 2005).

The initiation of vein opening by hydraulic fracturing is supported by observations of the textures of the satin spar veins. The gypsum veins in the study area exhibit typical characteristics of antitaxial veins (c.f. Durney and Ramsay, 1973; Cox, 1987). Median zones in such veins mark the initial site of fracturing and provide important information about how vein opened (Durney and Ramsay, 1973; Oliver and Bons, 2001; Bons and Montenari, 2005). Blocky textures of median zones were suggested to result from growth competition between crystals, which is likely to occur in open spaces (Fisher and Brantley, 1992; Bons, 2001), such as fluid-filled voids or fracture channels. It may be that gypsum precipitated into newly opened fractures because a concomitant drop in fluid pressure occurred that resulted in supersaturation. Or it may be that fracture opening produced a pore space large enough for already-supersaturated fluid to nucleate gypsum crystals. In either case, gypsum precipitation into hydraulic fractures partially or fully closed the fractures to fluid flow (Oliver and Bons, 2001). Therefore, the fracturing did not result in a general decrease in fluid pressure. Consequently, the fractures anneal, fluid pressure could then undergo a renewed increase (Oliver and Bons, 2001). Crack-seal texture indicates that the fractures were then reactivated and reopened as weak planes upon sufficient overpressure buildup. Pressure build-up could be the result of cyclic inversion stresses, erosional unloading during exhumation (c.f. Ingram et al. 2004), a high hydraulic head gradient at shallow depths, and/or a reduction of permeability in the mudrocks. In this way, the fluctuation in fluid pressure could result in repeated cracking in single veins (Barker, 2013).

2010), which is accompanied with the introduction of one or two host rock inclusion bands. 
392 Hence, the crack-seal mechanism (Ramsay, 1980; Cox and Etheridge, 1983; van der Pluijm, 393 1984; Laubach et al., 2004) is favoured in this study to explain the formation process of the 394 median zone. Syntectonic strata buckling (Machel, 1985; Teixell et al., 2000) and sediment 395 unloading (Mohamed El Tabakh and Warren, 1998; Teixell et al., 2000) could also contribute to 396 the generation of sub-horizontal hydraulic fractures, where they exploit bedding planes and 397 fissures as weak planes (Shearman et al., 1972). Another factor to be considered is that the veins 398 formed within the gypsum stability field (see below) and therefore close to a free boundary, i.e. 399 the surface. Overpressure could then be expected to form horizontal fractures, particularly if the 400 near-surface stresses were horizontally compressive (e.g. Sheorey, 1994). The lack of median 401 zones in some branches of satin spar vein suggests that vein branching occurred during 402 incremental fibre growth and postdates the primary hydraulic fracturing (Fig. 15).

403

\subsection{Fracture filling by satin spar}

404 Fibrous gypsum on both sides of the median zone exhibits contrasting crystal morphologies and 405 sizes to those in the median zone (Fig. 7), indicating a different formation mechanism (Bons and 406 Montenari, 2005). The gypsum fibres with no signs of brittle failure and straining suggest a 407 continuous rather than episodic growth more typically expected from a process involving pore 408 fluid pressure build-up and release (Koehn et al., 2000; Barker et al., 2006). The question then 409 arises regarding the origin of the fibrous habit of gypsum.

410 Previous studies suggested that crystal morphology in mineral veins is closely associated with 411 growth competition (Bons and Jessell, 1997; Means and Li, 2001; Wiltschko and Morse, 2001;

412 Hilgers and Urai, 2002). A lack of growth competition results in fibrous crystals, which only 413 occurs in limited spaces, especially in fractures or voids with width less than $10 \mathrm{um}$, or even 
414 completely closed (Hilgers and Urai, 2002). Moreover, laboratory and numerical simulation of

415 polycrystal growth suggest that growth competition may be inhibited when the growth rate of 416 crystals exceeds the opening rate of cracks (Hilgers et al., 2001; Means and Li, 2001). Hence,

417 nucleation of fibrous crystals on interfaces between host rocks and walls of median zones 418 appears to postdate the sealing of the initial hydraulic fractures by mosaic crystals, as discussed 419 above.

420 Vein expansion and fibre growth requires continued gypsum precipitation from supersaturated 421 fluids (Cobbold and Rodrigues, 2007). Advective porous flow is unlikely to carry nutrient for the

422 fibres due to the low-permeability bulk rock, especially when hydraulic fractures became sealed.

423 Diffusion, driven by concentration gradient, could then be responsible for nutrient transport to 424 satin spars (Fisher and Brantley, 1992; Bons et al., 2012; Rustichelli et al., 2016). Moreover, the 425 much greater length of fibres than the width of median zones requires a vast amount of solution, 426 which is unlikely to be transported by fluid flow in the bulk rock except through fractures. Hence, 427 the continuous growth of fibres is attributed to diffusion of gypsum in the sediment pore network 428 that is not necessarily accompanied by fluid flow and vein re-opening.

$429 \quad$ 10.3. Timing and Phases of Veins

430 Gypsum in the subsurface readily dehydrates and converts to anhydrite when the ambient 431 temperature rises up to $50-60^{\circ} \mathrm{C}$ (Testa and Lugli, 2000). Satin spar veins, which are considered 432 to be filled with secondary gypsum, are suggested to occur at a relative shallow depth and a low 433 ambient temperature. Coupled with the subsidence history of the Mercia Mudstone Group in the 434 BCB (Kamerling, 1979), the development of veins is constrained to occur during the last uplift 435 stage of the basin evolution. The diagenetic regenerated gypsum is likely to have resulted from 
436 hydration of anhydrite when the evaporite beds were uplifted shallow enough that they entered

437 the telogenetic zone and came into contact with low salinity meteoric waters. However, based on

438 the crack-seal texture within the median zones of fractures, and precipitation of gypsum upon

439 faults moving in response to basin inversion, we suggest that the initiation of veins was not 440 triggered by the gypsum-anhydrite transition but by fluid overpressure. Later widening, 441 propagation, and linking likely owe to swelling related to anhydrite hydration.

442 The initial opening of the veins is interpreted to be the result of hydraulic fracturing due to 443 overpressure developed during the tectonic compression during basin inversion (c.f. Cosgrave, 444 2001), and help infer the timing of the veins to be broadly connected to the last inversion episode.

445 The fault veins that developed within the fault zones of the reactivated faults (Figs 10-13), 446 possibly suggest that some of the gypsum-rich fluids were transported along those faults during 447 fault dilation possibly as a result of seismic pumping behavior (Sibson et al., 1975).

448 As evident from the widely observed obliquity of fibres with respect to vein walls, the satin spar 449 veins are interpreted to be hybrid veins. Given the geometric patterns and lack of any systematic 450 cross-cutting relationships between differently oriented veins in the Keuper Marl, we infer a 451 small effective differential stress $(<4 \mathrm{~T})$ at this time of vein initiation (Fig. 16). Such a stress field 452 is consistent with the generation of anastomosing fracture networks with frequent fracture 453 abutting and branching. However, we interpret the clear cross-cutting relationship between the 454 two sets of veins in the Tea Green Marl to mean at least two phases of fracturing.

455 Fault reactivation in the study area and adjacent areas of the Bristol Channel Basin is commonly 456 marked by slickenfibres with steps facing up-dip (Figs 10 and 13) (also Glen et al., 2005). The 457 two sets of fibre lineations in the median zone and on surfaces of fault vein possiblyindicate a 
458 minimum of two phases of fault reactivation. This interpretation is justified because such 459 lineations only reveal the last slip event, and lineation for earlier slips could have been obscured 460 or obliterated (Fossen, 2016). However, the pure, curved fibres in the fault veins (Figs 12C, 13B), 461 which exhibit significantly different crystal morphology from the lineations, are likely to have 462 formed during the inactivate period of the faults on the premise that mineral fibres could only 463 nucleated in limited-closed spaces (Hilgers and Urai, 2002).

464 An important clue for the timing of the satin spar veins is that the folds in the Tea Green Marl are 465 cut by the predominant sub-horizontal veins (Fig. 9F), suggesting the veins postdate the folding. 466 Given the inferred timing of fault reactivation and buttress folding from late Oligocene to 467 Miocene (Engelder and Peacock, 2001; Glen et al., 2005) as constraints, we infer that the satin 468 spar veins formed during the Miocene or later.

\section{10.4. Summary of Vein Genesis}

470 Based on field and petrographic observations, a generic model is introduced to explain the

471 dynamic process of the formation and growth of satin spar veins in mudstones. Initially,

472 numerous discrete hydraulic fractures are generated in low-permeability mudstones due to 473 overpressure, itself caused by inversion-related compression. Injection of sulphate-rich waters 474 into fractures, including both the pre-existing and newly formed fractures, leads to rapid 475 precipitation of equant, albastrine gypsum on fracture walls as a result of the dramatic drop in 476 fluid pressure, and healing of fractures. Due to the drop in fracture permeability, pore pressure 477 could rise again, leading to vein reopening at vein-wall interfaces. This is accompanied with 478 wall-parallel host rock bands detached from wall rocks. Such a process could occur repeatedly, 479 producing a blocky, crack-seal texture in the median zone. After the cessation of fault 
480 reactivations, pore pressure was not elevated so high as to reopen the healed veins. At this stage,

481 satin spars, which are fed by nutrient through diffusion, start to nucleate on the walls of the

482 blocky veins and grow continuously without further fracturing. This diffusion was driven by the

483 relative thermodynamic stability of gypsum at shallow depths.

\section{11. Conclusions}

485 (1) The satin spar veins initiated as natural hydraulic fractures or reactivated fractures in the low486 permeability marls of the Triassic Mercia Mudstone as a result of overpressure during basin 487 inversion.

488 (2) The satin spar veins exhibit characteristic features of antitaxial growth, but the blocky median 489 zone contains multiple bands of host rock inclusions and equant alabastrine gypsum, indicating 490 an origin comprising crack-seal events.

491 (3) Satin spar veins filling reactivated faults contain fibre lineations in the median zone and on 492 vein surfaces, indicating at least two phases of fault slip.

493 (4) The cross-cutting relationships between satin spar veins and other structures suggest the 494 formation timing to be Miocene.

495 (5) Fibre growth in satin spar veins was continuous and did not re-open veins; this later phase of 496 vein growth postdates initial hydrofracturing and sealing, and resulted from diffusion during the 497 anhydrite-gypsum transition. 
498 (6) The satin spar veins of the Mercia Mudstone in the study area constitute an ideal analogue to 499 subsurface hydraulic fracture systems in mudstone. However, their expansion owes to later 500 diagenesis, which widened fractures and increased their connectivity.

\section{Acknowledgements}

502 This research is funded by Shell International Exploration and Production B.V. We thank Jon 503 Wells for sample preparation, and Rick Allmendinger for providing Stereonet 9 software. We 504 also thank Bruce Levell, Steve Hesselbo and Micha Ruhl for beneficial discussions. William 505 Dunne is thanked for editorial handling of this manuscript. The thoughtful comments and 506 constructive suggestions by the editor, Paul Bons and Brent Couzens-Schultz greatly improved 507 the quality of this paper.

\section{References}

509 Arvidson, R., Squyres, S., Bell, J., Catalano, J., Clark, B., Crumpler, L., De Souza, P., Fairén, A., Farrand, W., and Fox, V., 2014. Ancient aqueous environments at Endeavour crater, Mars. Science 343, 1248097.

512 Barker, S. L., Cox, S. F., Eggins, S. M., and Gagan, M. K., 2006. Microchemical evidence for

Barker, A. J., 2013. Introduction to metamorphic textures and microstructures. Routledge.

516 Bons, P. D., and Jessell, M. W., 1997. Experimental simulation of the formation of fibrous veins by localised dissolution-precipitation creep. Mineralogical Magazine 61, 53-63.

518 Bons, P. D., 2000. The formation of veins and their microstructures. Journal of the Virtual 519 Explorer 2, 12. 
Bons, P., 2001. Development of crystal morphology during unitaxial growth in a progressively widening vein: I. The numerical model. Journal of Structural Geology 23, 865-872.

Bons, P. D., and Montenari, M., 2005. The formation of antitaxial calcite veins with welldeveloped fibres, Oppaminda Creek, South Australia. Journal of Structural Geology 27, 231-248.

Bons, P. D., Elburg, M. A., and Gomez-Rivas, E., 2012. A review of the formation of tectonic veins and their microstructures. Journal of Structural Geology 43, 33-62.

Brooks, M., Trayner, P., and Trimble, T., 1988. Mesozoic reactivation of Variscan thrusting in the Bristol Channel area, UK. Journal of the Geological Society 145, 439-444.

Chadwick, R., 1986. Extension tectonics in the Wessex Basin, southern England. Journal of the Geological Society 143, 465-488.

Cobbold, P. R., and Rodrigues, N., 2007. Seepage forces, important factors in the formation of horizontal hydraulic fractures and bedding-parallel fibrous veins (beef and cone-in-cone). Geofluids 7, 313-322.

Cobbold, P. R., Zanella, A., Rodrigues, N., and Løseth, H., 2013. Bedding-parallel fibrous veins (beef and cone-in-cone): worldwide occurrence and possible significance in terms of fluid overpressure, hydrocarbon generation and mineralization. Marine and Petroleum Geology, 43, 1-20.

Cosgrove, J., 1993. The interplay between fluids, folds and thrusts during the deformation of a sedimentary succession. Journal of Structural Geology 15, 491-500.

Cosgrove, J., 1995. The expression of hydraulic fracturing in rocks and sediments. Geological Society, London, Special Publications 92, 187-196. 
542 Cosgrove, J. W., 2001. Hydraulic fracturing during the formation and deformation of a basin: A 543 factor in the dewatering of low-permeability sediments. AAPG Bulletin 85, 737-748.

544 Couzens-Schultz, B. A., and Azbel, K., 2014. Predicting pore pressure in active fold-thrust 545 systems: An empirical model for the deepwater Sabah foldbelt. Journal of Structural 546 Geology 69, 465-480.

547 Coward, M., 1995. Structural and tectonic setting of the Permo-Triassic basins of northwest 548 Europe. Geological Society, London, Special Publications 91, 7-39.

549 Cox, S., and Etheridge, M., 1983. Crack-seal fibre growth mechanisms and their significance in 550 the development of oriented layer silicate microstructures. Tectonophysics $92,147-170$.

551

552

553

554 555

Dart, C. J., McClay, K., and Hollings, P. N., 1995. 3D analysis of inverted extensional fault systems, southern Bristol Channel basin, UK. Geological Society, London, Special Publications 88, 393-413.

De Meer, S., and Spiers, C.J., 1995. Creep of wet gypsum aggregates under hydrostatic loading conditions. Tectonophysics 245: 171-183.

De Meer, S., and Spiers, C.J., 1997. Uniaxial compaction creep of wet gypsum aggregates. Journal of Geophysical Research: Solid Earth 102: 875-891.Donato, J., 1988. Possible Variscan thrusting beneath the Somerton anticline, Somerset. Journal of the Geological Society $145,431-438$.

Durney, D. W., and Ramsay, J., 1973. Incremental strains measured by syntectonic crystal growths. Gravity and tectonics 67, 96.

Engelder, T., and Peacock, D. C., 2001. Joint development normal to regional compression during flexural-flow folding: the Lilstock buttress anticline, Somerset, England. Journal of Structural Geology 23, 259-277. 
574

575 576

Fisher, D. M., and Brantley, S. L., 1992. Models of quartz overgrowth and vein formation: deformation and episodic fluid flow in an ancient subduction zone. Journal of Geophysical Research: Solid Earth 97, 20043-20061.

Fossen, H., 2016. Structural geology. Cambridge University Press.

Gale, J. F., and Holder, J., 2010. Natural fractures in some US shales and their importance for gas production. Geological Society, London, Petroleum Geology Conference Series 7, $1131-1140$.

Glen, R., Hancock, P., and Whittaker, A., 2005. Basin inversion by distributed deformation: the southern margin of the Bristol Channel Basin, England. Journal of Structural Geology 27, 2113-2134.

Gustavson, T. C., Hovorka, S. D., and Dutton, A. R., 1994. Origin of satin spar veins in evaporite basins. Journal of Sedimentary Research 64, 88-94.

Hilgers, C., Koehn, D., Bons, P., and Urai, J., 2001. Development of crystal morphology during unitaxial growth in a progressively widening vein: II. Numerical simulations of the evolution of antitaxial fibrous veins. Journal of Structural Geology 23, 873-885.

Hilgers, C., and Urai, J. L., 2002. Microstructural observations on natural syntectonic fibrous veins: implications for the growth process. Tectonophysics 352, 257-274.

Hobbs, P., Hallam, J., Forster, A., Entwisle, D., Jones, L., Cripps, A., Northmore, K., Self, S., and Meakin, J., 2002. Engineering geology of British rocks and soils: Mudstones of the Mercia Mudstone Group. British Geological Survey.

Holford, S. P., Turner, J. P., and Green, P. F., 2005. Reconstructing the Mesozoic-Cenozoic exhumation history of the Irish Sea basin system using apatite fission track analysis and 
vitrinite reflectance data. Geological Society, London, Petroleum Geology Conference series 6, 1095-1107.

589

590

591

592

593

594

595

596

597

598

599

600

601

602

603

604

605

606

607
Holloway, S., and Chadwick, R., 1986. The Sticklepath-Lustleigh fault zone: Tertiary sinistral reactivation of a Variscan dextral strike-slip fault. Journal of the Geological Society 143, 447-452.

Howard, A., Warrington, G., Ambrose, K., and Rees, J., 2008. A formational framework for the Mercia Mudstone Group (Triassic) of England and Wales. British Geological Survey.

Ingram, G., Chisholm, T., Grant, C., Hedlund, C., Stuart-Smith, P., and Teasdale, J., 2004. Deepwater North West Borneo: hydrocarbon accumulation in an active fold and thrust belt. Marine and Petroleum Geology 21, 879-887.

Kamerling, P., 1979. The geology and hydrocarbon habitat of the Bristol Channel Basin. Journal of Petroleum Geology 2, 75-93.

Keary, P., and Vine, F., 1990. Global Tectonics. Blackwell, Oxford.

Kelly, P., Peacock, D., Sanderson, D., and McGurk, A., 1999. Selective reverse-reactivation of normal faults, and deformation around reverse-reactivated faults in the Mesozoic of the Somerset coast. Journal of Structural Geology 21, 493-509.

Koehn, D., Hilgers, C., Bons, P. D., and Passchier, C. W., 2000. Numerical simulation of fibre growth in antitaxial strain fringes. Journal of Structural Geology 22, 1311-1324.

Laubach, S., Reed, R., Olson, J., Lander, R., and Bonnell, L., 2004. Coevolution of crack-seal texture and fracture porosity in sedimentary rocks: cathodoluminescence observations of regional fractures. Journal of Structural Geology 26, 967-982. 
608 Luo, X., Wang, Z., Zhang, L., Yang, W., and Liu, L., 2007. Overpressure generation and 609 evolution in a compressional tectonic setting, the southern margin of Junggar Basin, northwestern China. AAPG Bulletin 91, 1123-1139.

611

Machel, H. G., 1985. Fibrous gypsum and fibrous anhydrite in veins. Sedimentology 32, 443-454.

612 Mandl, G., 2005. Rock joints. Springer, Berlin.

613 Mauldon, M., Dunne, W., and Rohrbaugh, M., 2001. Circular scanlines and circular windows:

614

615 new tools for characterizing the geometry of fracture traces. Journal of Structural Geology 23, 247-258.

Means, W., and Li, T., 2001. A laboratory simulation of fibrous veins: some first observations. Journal of Structural Geology 23, 857-863.

Menpes, R. J., and Hillis, R. R., 1995. Quantification of Tertiary exhumation from sonic velocity 619 data, Celtic Sea/south-western approaches. Geological Society, London, Special Publications 88, 191-207.

621

622

623

624 625 626 627 628 629 630
Miliorizos, M., and Ruffell, A., 1998. Kinematics of the Watchet-Cothelstone-Hatch fault system: implications for the fault history of the Wessex basin and adjacent areas. Geological Society, London, Special Publications 133, 311-330.

Mohamed El Tabakh, B., and Warren, J. K., 1998. Origin of fibrous gypsum in the Newark rift basin, eastern North America. Journal of Sedimentary Research 68, 88-99.

Moragas, M., Martínez, C., Baqués, V., Playà, E., Travé, A., Alías, G., and Cantarero, I., 2013. Diagenetic evolution of a fractured evaporite deposit (Vilobí Gypsum Unit, Miocene, NE Spain). Geofluids 13, 180-193.

Murray, R., 1964. Origin and diagenesis of gypsum and anhydrite. Journal of Sedimentary Research 34, 512-523. 
631 Nachon, M., Clegg, S., Mangold, N., Schröder, S., Kah, L., Dromart, G., Ollila, A., Johnson, J.,

632

633

634

635

636

637

638

639

640

641

642

643

644

645

646

647

648

649

650

651

652

653
Oehler, D., and Bridges, J., 2014. Calcium sulfate veins characterized by ChemCam/Curiosity at Gale crater, Mars. Journal of Geophysical Research: Planets 119, 1991-2016.

Nemčok, M., Gayer, R., and Miliorizos, M., 1995. Structural analysis of the inverted Bristol Channel Basin: implications for the geometry and timing of fracture porosity. Geological Society, London, Special Publications 88, 355-392.

Nichols, G., 2009. Sedimentology and stratigraphy. John Wiley \& Sons.

Oliver, N. H., and Bons, P. D., 2001. Mechanisms of fluid flow and fluid-rock interaction in fossil metamorphic hydrothermal systems inferred from vein-wallrock patterns, geometry and microstructure. Geofluids 1, 137-162.

Passchier, C. W., and Trouw, R. A., 1996. Microtectonics. Springer, Berlin.

Peacock, D., and Sanderson, D., 1991. Displacements, segment linkage and relay ramps in normal fault zones. Journal of Structural Geology 13, 721-733.

Peacock, D., 1992. Effects of layering and anisotropy on fault geometry. Journal of the Geological Society 149, 793-802.

Peacock, D, 1994. Geometry and development of relay ramps in normal fault systems. AAPG Bulletin 78, 147-165.

Peacock, D, 1999. Deformation history and basin-controlling faults in the Mesozoic sedimentary rocks of the Somerset coast. Proceedings of the Geologists' Association 110, 41-52.

Philipp, S. L., 2008. Geometry and formation of gypsum veins in mudstones at Watchet, Somerset, SW England. Geological Magazine 145, 831-844.

Ramsay, J. G., 1980. The crack-seal mechanism of rock deformation. Nature 284, 135-139. 
654 Rawnsley, K., Peacock, D., Rives, T., and Petit, J.-P., 1998. Joints in the Mesozoic sediments 655 around the Bristol Channel Basin. Journal of Structural Geology 20, 1641-1661.

Roberts, D., 1989. Basin inversion in and around the British Isles. Geological Society, London, Special Publications 44, 131-150.

Ruffell, A., and Coward, M., 1992. Basement tectonics and their relationship to Mesozoic megasequences in the Celtic Seas and Bristol Channel area. Geological Society, London, Special Publications 62, 385-394.

Ruffell, A., and Shelton, R., 1999. The control of sedimentary facies by climate during phases of crustal extension: examples from the Triassic of onshore and offshore England and Northern Ireland. Journal of the Geological Society 156, 779-789.

Rustichelli, A., Di Celma, C., Tondi, E., Baud, P., and Vinciguerra, S., 2016. Fibrous gypsum veins as diffuse features and within fault zones: the case study of the Pisco Basin (Ica desert, southern Peru). Journal of the Geological Society 173, 405-418.

Shearman, D., Mossop, G., Dunsmore, H., and Martin, M., 1972. Origin of gypsum veins by hydraulic fracture. Institution of Mining and Metallurgy Transaction, Section B: Applied Earth Science 81, 149-155.

Sheorey, P.R., 1994. A theory for in situ stresses in isotropic and transversely isotropic rock. International Journal of Rock Mechanics and Mining Sciences 31 (1), 23-34.

Sibson, R., Moore, J. M. M., and Rankin, A., 1975. Seismic pumping-a hydrothermal fluid transport mechanism: Journal of the Geological Society 131, 653-659.

Squyres, S. W., Arvidson, R. E., Bell, J., Calef, F., Clark, B., Cohen, B., Crumpler, L., De Souza, P., Farrand, W., and Gellert, R., 2012. Ancient impact and aqueous processes at Endeavour Crater, Mars. Science 336, 570-576. 
677 Talbot, M., Holm, K., and Williams, M., 1994. Sedimentation in low-gradient desert margin

678

679

680

681

682

683

684

685

686

687

688

689

690

691

692

693

694

695

696

697 systems: A comparison of the Late Triassic of northwest Somerset (England) and the late Quaternary of east-central Australia. Geological Society of America Special Papers 289, 97-117.

Teixell, A., Durney, D. W., and Arboleya, M.-L., 2000. Stress and fluid control on décollement within competent limestone. Journal of Structural Geology 22, 349-371.

Testa, G., and Lugli, S., 2000. Gypsum-anhydrite transformations in Messinian evaporites of central Tuscany (Italy). Sedimentary Geology 130, 249-268.

Tucker, M., 1977. The marginal Triassic deposits of South Wales: continental facies and palaeogeography. Geological Journal 12, 169-188.

Tucker, M. E., 2009. Sedimentary petrology: an introduction to the origin of sedimentary rocks. John Wiley \& Sons.

Van der Pluijm, B. A., 1984. An unusual 'crack-seal' vein geometry. Journal of structural geology 6, 593-597.

Van Hoorn, B., 1987. The south Celtic Sea/Bristol Channel Basin: origin, deformation and inversion history. Tectonophysics 137, 309-334.

Virgo, S., Abe, S., and Urai, J.I., 2014. The evolution of crack seal vein and fracture networks in an evolving stress field: insights from discrete element models of fracture sealing. Journal of Geophysical Research: Solid Earth 119, 8708-8727.

Warren, J. K., 2006. Evaporites: sediments, resources and hydrocarbons. Springer Science \& Business Media. 
698 Warrington, G., Cope, J., and Ivimey-Cook, H., 1994. St Audrie's Bay, Somerset, England: a 699 candidate global stratotype section and point for the base of the Jurassic system.

700 Geological Magazine 131, 191-200.

701 Whittaker, A., 1972. The Watchet Fault — a post Liassic transcurrent reverse fault. Bulletin of the 702 Geological Survey 41, 75-80.

703 Whittaker, A., and Green, G. W., 1983. Geology of the country around Weston-super-Mare. HM 704 Stationery Office.

705 Wiltschko, D. V., and Morse, J. W., 2001. Crystallization pressure versus "crack seal" as the 706 mechanism for banded veins. Geology 29, 79-82. 
Fig. 1. Geological map of the study area (A) on the Warren Bay; and (B) cross-section along AA' line. Locations for Figs. 3A, 3C, 4A-B, 5A-D, 5E-F, 10-12, and 13A are shown in Fig. 1A. BCB, Bristol Channel Basin. Vein (black) and bedding (bold) orientation data plotted on stereonets as great circles (lower hemisphere). See vein orientation data in Table S1 (supplementary material). Geological map is modified from Dart et al. (1995) and Glen et al. (2005).

Fig. 2. Stratigraphic column of the Triassic and Early Jurassic of the BCB. Adapted from Hobbs et al. (2002).

Fig. 3. Outcrop photographs showing sandstone dykes in the Keuper Marl. (A) A normal fault cross-cuts a sandstone dyke (yellow-dotted line). The enlarged box shows a gypsum nodule being cross-cut by the sandstone dyke. The arrows show the nodular gypsum horizons as markers for bedding correlation. See location in Fig. 1A. (B) A steeply dipping sandstone dyke cross-cuts multiple nodular gypsum horizons. The enlarged area shows the sub-horizontal satin spar veins cross-cutting the sandstone dyke. (C) A curved sandstone dyke cross-cut by subhorizontal satin spar veins. HRF, host rock fragment. Hammer is $30 \mathrm{~cm}$ long. See location in Fig. 1A. (D) Sketch of Fig. 3C.

Fig. 4. Outcrop photographs showing inversion-related structures. (A) Buttress folding of the layers of the TGM in the hanging wall of the Helwell Bay Fault. The faults are highlighted by red lines. 1, gently inclined satin spar veins cross-cut folded layers of the TGM. 2, beddingparallel veins in the KM cross-cut by the Helwell Bay Fault. (B) Detachment folds of the layers of the Blue Lias Formation above weak layers of the TGM with abundant nodular gypsum. Note that the fold is modified by some reverse faults. See location in Fig. 1A. BL, Blue Lias 
Formation. HBF, Helwell Bay Fault. KM, Keuper Marl. TGM, Tea Green Marl. NG, nodular gypsum.

Fig. 5. Outcrop photographs showing satin spar veins in the Keuper Marl (A-D) and the Tea Green Marl (E-F). (A) Anastomosing satin spar vein network. (B) Closely spaced sub-horizontal satin spar veins. Notebook is $15 \mathrm{~cm}$ long. (C) Vein networks showing three major preferred orientations (normal to arrows). The circle shows the circular window for vein orientation measurement. Tape measure is $1 \mathrm{~m}$ long. (D) A short vein with tapering tips. (E) Slabs of red steep veins exposed in the cliffs. Note the white vein cross-cuts the red veins. Note book is 20 $\mathrm{cm}$ in length. (F) Sigmoidal shaped red, intact veins in gently dipping beds. See locations in Fig. $1 \mathrm{~A}$.

Fig. 6. En echelon veins in the outcrop (A-B) and thin sections (C-H). (A) A sub-horizontal vein in the Keuper Marl with host rock fragments which are oblique to vein walls. UTM position: Northing 5670230, Easting 476433, Zone 30U. (B) Sigmoidal shaped veins in the Tea Green Marl. UTM position: Northing 5670064, Easting 475911, Zone 30U. (C) A set of small en echelon veins in red marls. (D) The coalescence of two parallel veins, leaving the host rock fragment trapped between the vein tips. (E) A vein with impurities of oblique host rock inclusions. Samples in Fig. 6C-E are from the same site as the vein in Fig. 6A. (F) Sketch of Fig. 6E. (G) A sub-horizontal vein with four wall-oblique host rock fragments. UTM position: Northing 5670116, Easting 476016, Zone 30U. (H) Sketch of Fig. 6G.

Fig. 7. Outcrop photographs (A-B) and photomicrographs (C-F) showing texture and composition of satin spar veins. (A) A sub-horizontal satin spar vein in the Keuper Marl. Note that the fibres are oblique to vein walls. Camera diameter is $5.2 \mathrm{~cm}$. (B) A sub-horizontal vein 
consisting of a dark median zone and two fibrous zones on different sides of the median zone. Pen head is $5 \mathrm{~cm}$. (C) The blocky median zone of a representative satin spar vein, consisting of multiple thin bands of host rock inclusions and numerous interlocking alabastrine gypsum crystals. (D) Sketch of Fig. 7C. (E) A curved median zone of a satin spar vein. Note that the host rock inclusion bands are parallel to the margin of the median zone. (F) Parallel aligned fibres on one side of the median zone. The fibres show rather constant width and smooth crystal boundaries.

Fig. 8. Outcrop photographs (A-D) and photomicrographs (E) showing the behavior of vein branching. (A) A sub-horizontal vein splits into a sub-horizontal branch and an inclined branch. Note that the median zone (highlighted by arrows) is retained in the sub-horizontal branch. (B) Branching in both the upper and lower parts in a thick vein. (C) Coalescence of vein branches, resulting a connected vein network. (D) A thick vein split into three branches. (E) Multiple branches for a single satin spar vein. Cross polars.

Fig. 9. Intersection of differently oriented satin spar veins in the Keuper Marl (A-E) and the subhorizontal veins in the folded layers in the Tea Green Marl (F). (A) Intersection of veins of set K-1 and sub-horizontal veins of set K-3. Note that the veins do not cross-cut and instead, form an anastomosing network. (B) Coalescence of curved satin spar veins. (C) Coalescence of subhorizontal veins with steeply dipping veins. The enlarged box shows the tapering tip of a subhorizontal vein towards the steep vein. (D) Sub-horizontal veins with a steeply dipping step. (E) Steeply dipping veins formed as wing-cracks of thick sub-horizontal veins. Note the increase in vein aperture towards the sub-horizontal vein. (F) Curvy, sub-horizontal satin spar veins crosscut the folded layers in the Tea Green Marl. 
Fig. 10. Outcrop photograph showing a fault vein cross-cutting sub-horizontal veins in the bulk rock. UTM position: Northing 5670244, Easting 476500, Zone 30U. (A) The fault shows a reverse displacement. Note the sub-horizontal veins and nodular horizons (green-yellow arrows) as markers for bedding correlation. Tape measure is $1 \mathrm{~m}$ long. See location in Fig. 1A. (B) The plane of the fault vein with fibre lineations which are parallel to the striations in the wall rock in Fig. 10C. The dashed line mark lineation orientation. (D) Steps and depressions on the plane of the fault vein, which are interpreted to have been created during fault reverse slip.

Fig. 11. Outcrop photographs showing the fault vein filling the Helwell Bay Fault. UTM position: Northing 5670073, Easting 475929, Zone 30U. See location in Fig. 1A. (A) The fault vein crosscuts the white satin spar vein (arrows). (B) Fibre lineations in the fault vein, indicating the last slip direction of the fault. (C) Dark striations on a sub-horizontal fault vein. Pen is $15 \mathrm{~cm}$ long. (D) Propagation of a horizontal gypsum vein (yellow arrow) along the plane of a normal fault. UTM position: Northing 5670154, Easting 476101, Zone 30U.

Fig. 12. (A) Outcrop photograph showing a thick fault vein filling a normal fault. UTM position: Northing 5670248, Easting 476536, Zone 30U. See location in Fig. 1A. (B) The fault vein consists of impure median zones of gypsum and host rock inclusions. The outer parts contains pure, curved gypsum fibres. (C) Curved gypsum fibres with increased plunge towards the vein wall. See location in the box in Fig. 12B.

Fig. 13. (A) A fault with a reverse displacement, which is marked by the green siltstone layer (arrow). UTM position: Northing 5670231, Easting 476444, Zone 30U. See location in Fig. 1A. (B) The fault vein filling the fault in Fig. 13A. The dashed lines highlight the fibre traces. (C) 
Fibre lineations on the plane of the fault vein. Note the steps that indicate the reverse motion. (D) Sketch illustrating the representative textures of fault veins.

Fig. 14 Sketch illustrating repeated fault reactivation with fault vein-filling by gypsum. T1: The sediments were loaded with a maximum sub-horizontal compressive stress. T2: The faults were reactivated with reverse motions recorded by fibre lineations. T3: Pure gypsum fibres grew when the faults were inactive and fully sealed. T4: Fibre lineations were produced on the planes of fault veins during another phase of fault reactivation.

Fig. 15. Sketch illustrating the process of branching of satin spar veins. T1: Initial cracking. T2: Antitaxial growth of gypsum fibres. The fibres are gently inclined towards the left side of the figure because the resolved shear stress caused left-lateral relative motion of the vein walls. T3: Vein splitting during incremental widening of the vein. Note the bifurcation located in the fibrous zone rather than the median zone. The fibres in the thin branch are gently inclined towards the right side of the figure because its walls exhibit a right-lateral relative motion.

Fig. 16. (A) Subsidence curve for the Mercia Mudstone in the north Somerset region. Modified from Cosgrove (2001). Basin inversion is evident from fault reactivation. Vein generation is estimated to occur near surface with a horizontal maximum principal stress. (B) NavierCoulomb-Griffith combined extensional and shear brittle failure envelope showing the stress states which cause extensional (I, II and III) and shear-extensional failure (IV). I-II all have differential stresses less than $4 \mathrm{~T}$ ( $\mathrm{T}$, tensile strength). IV has a differential stress around 4T. Stress diagram is modified from Cosgrove (1995). (C) Field observations of vein network that are compatible with the stress states illustrated in II-IV, indicating a low differential stress causing the formation of satin spar veins. 



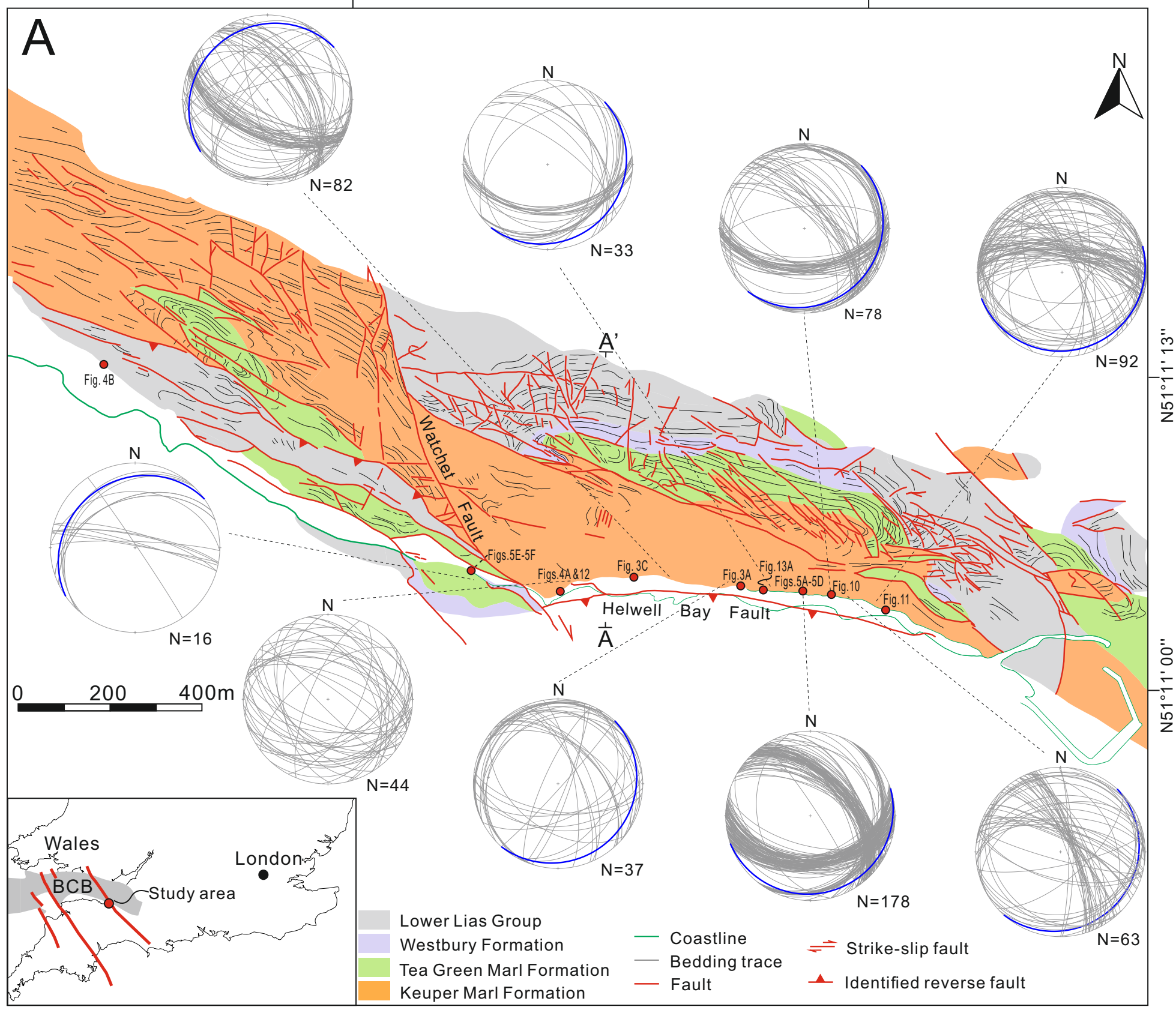

B

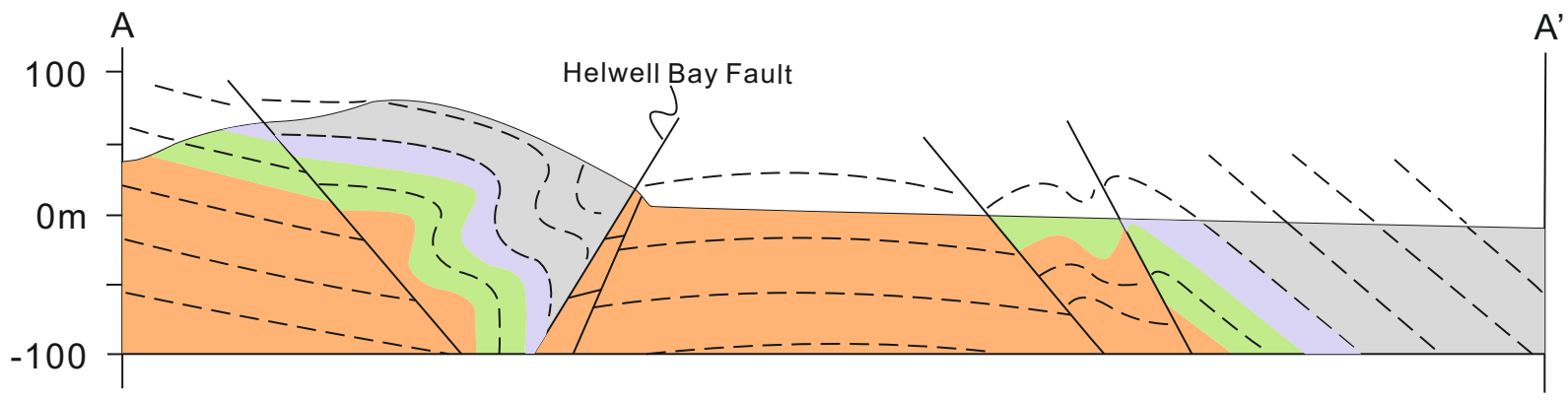




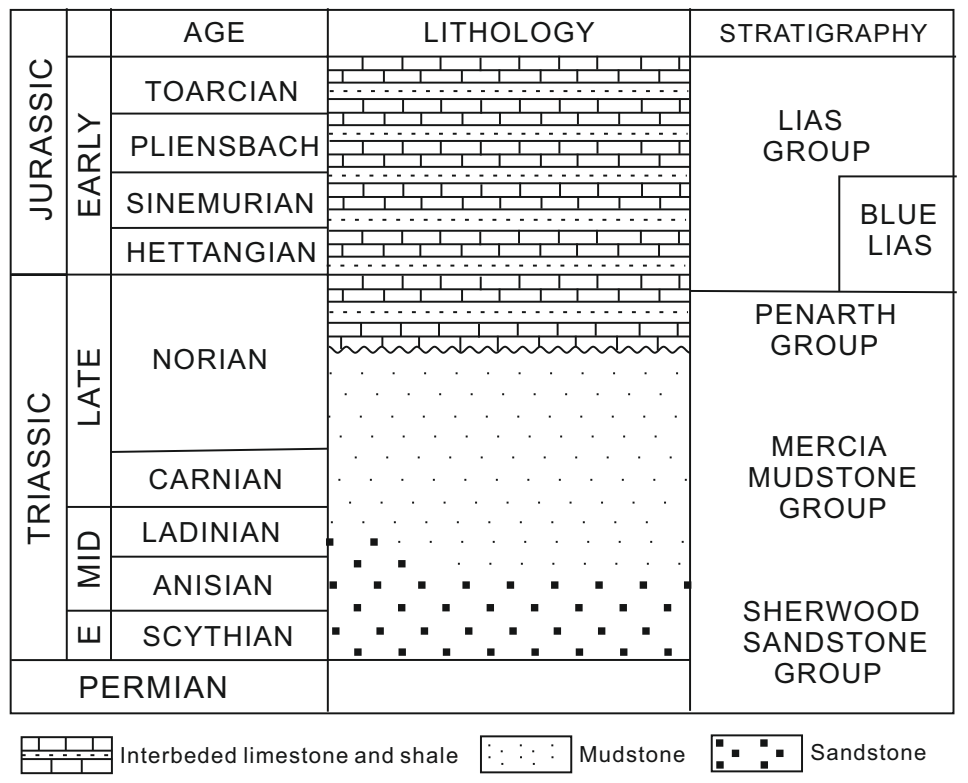



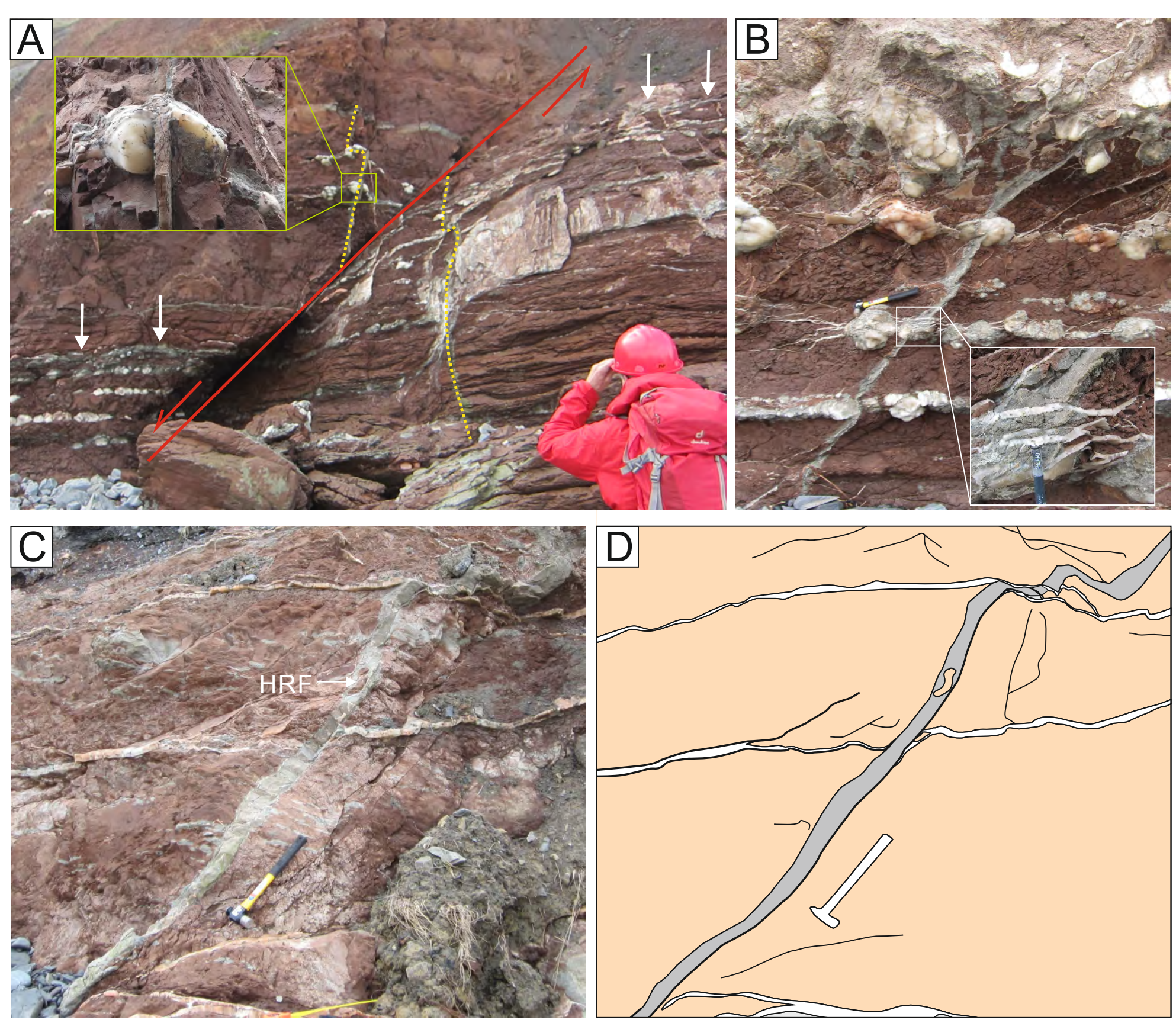


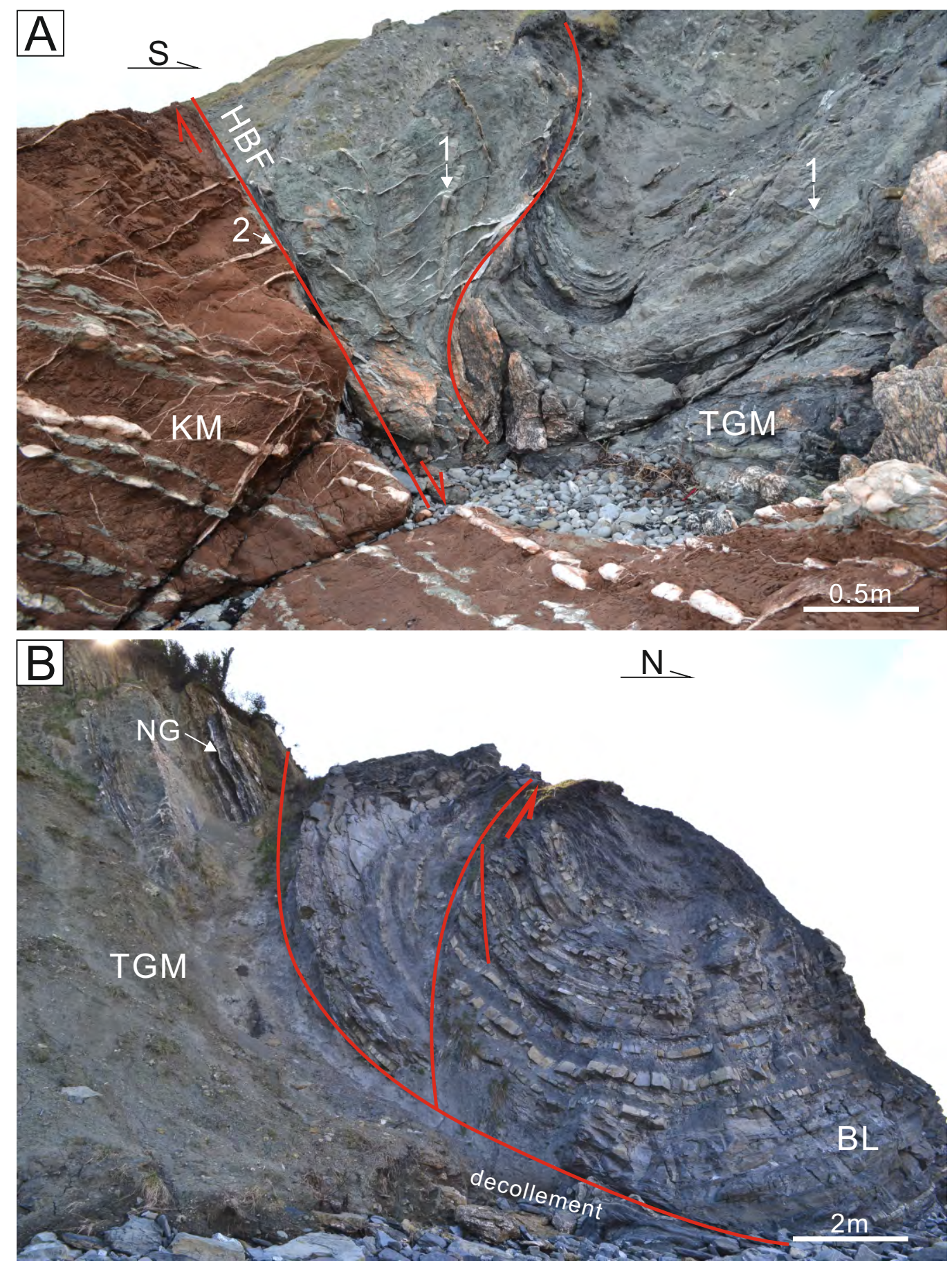



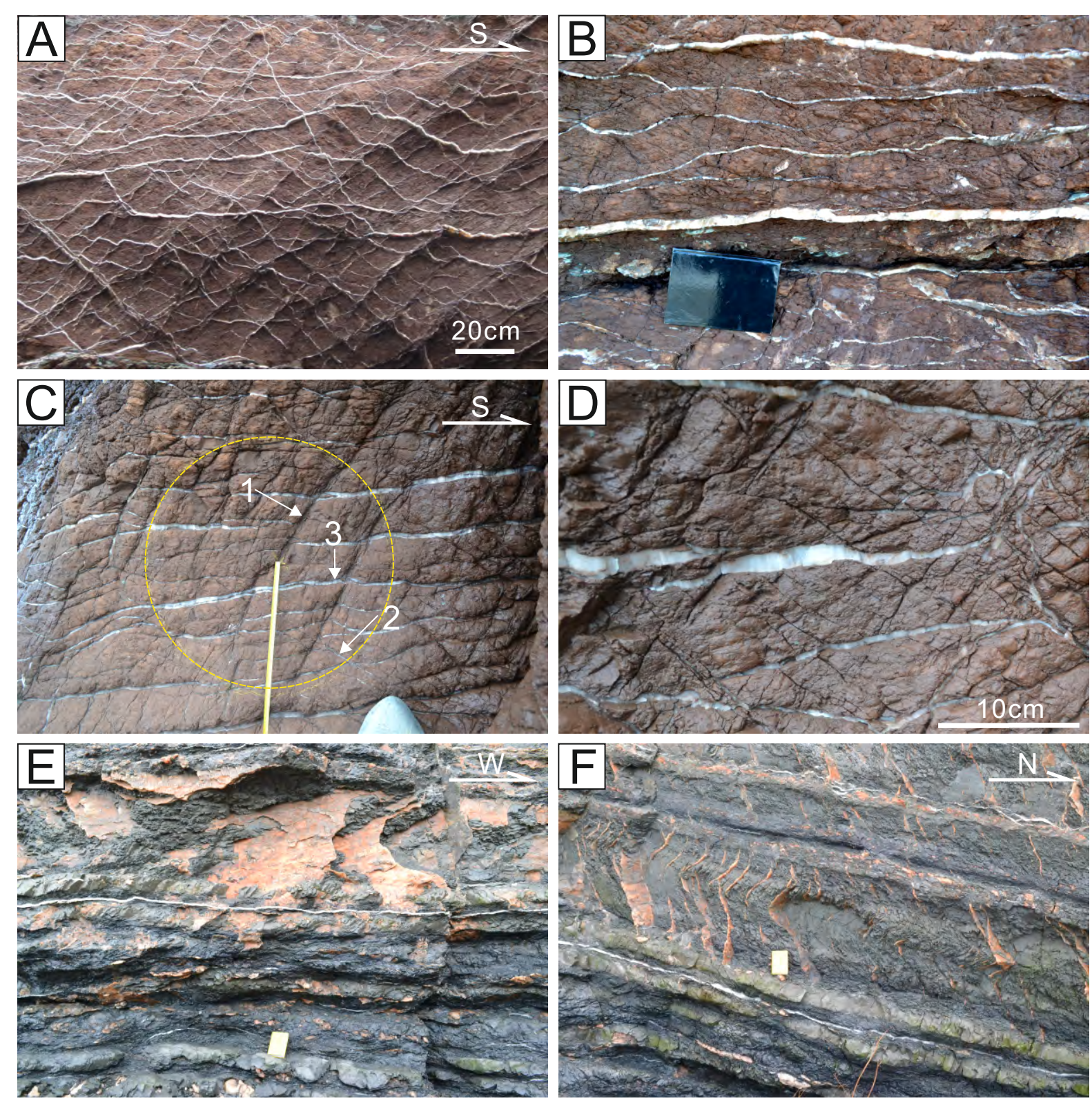

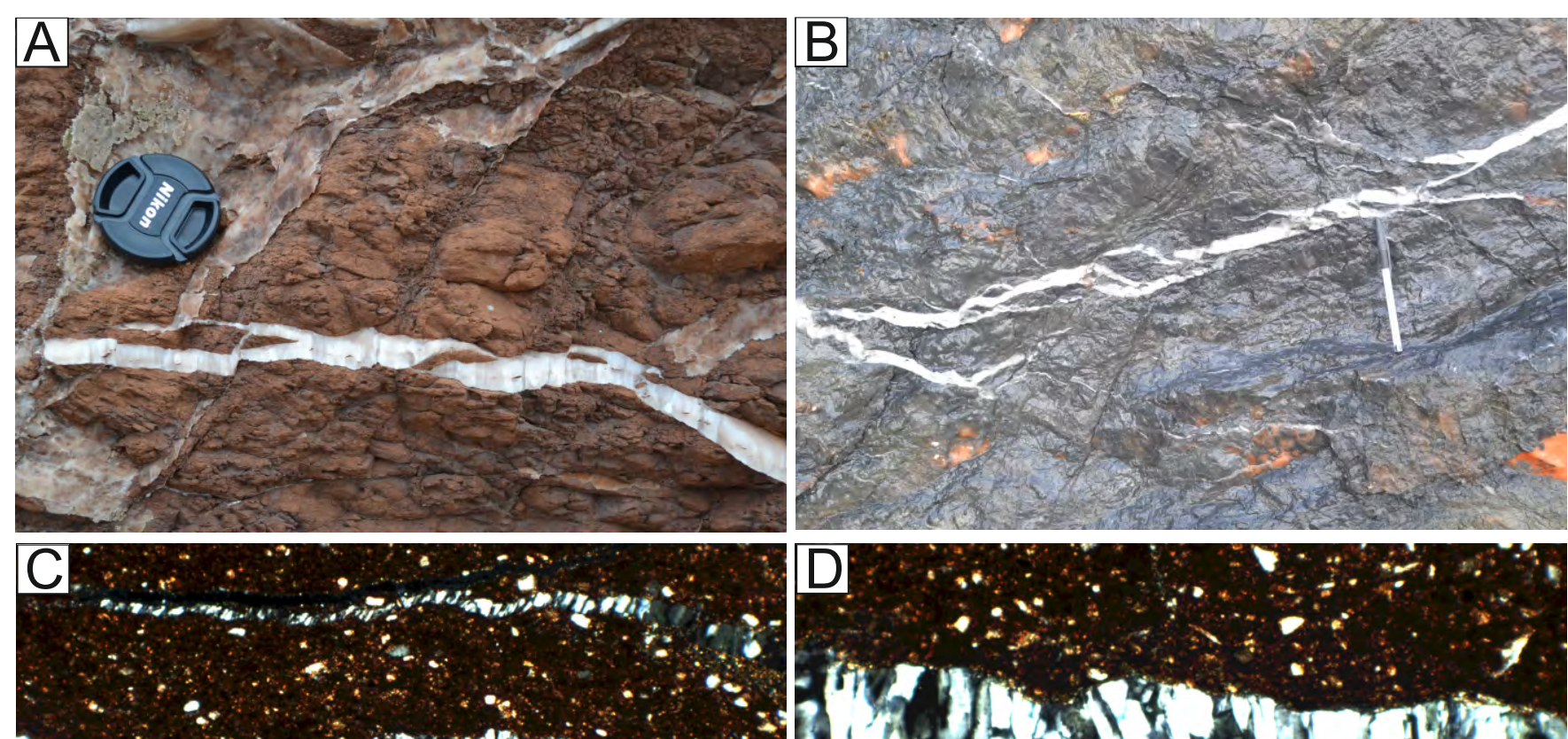

notonts

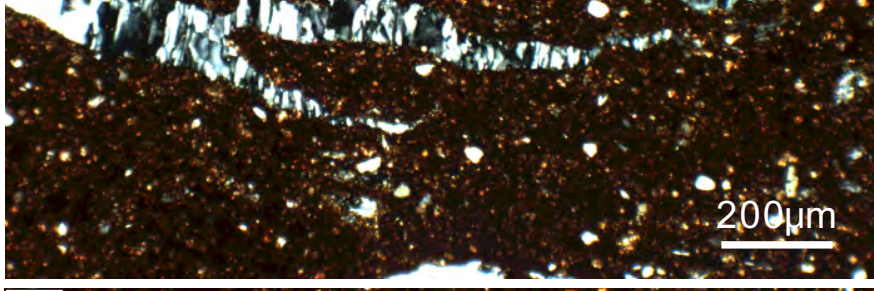
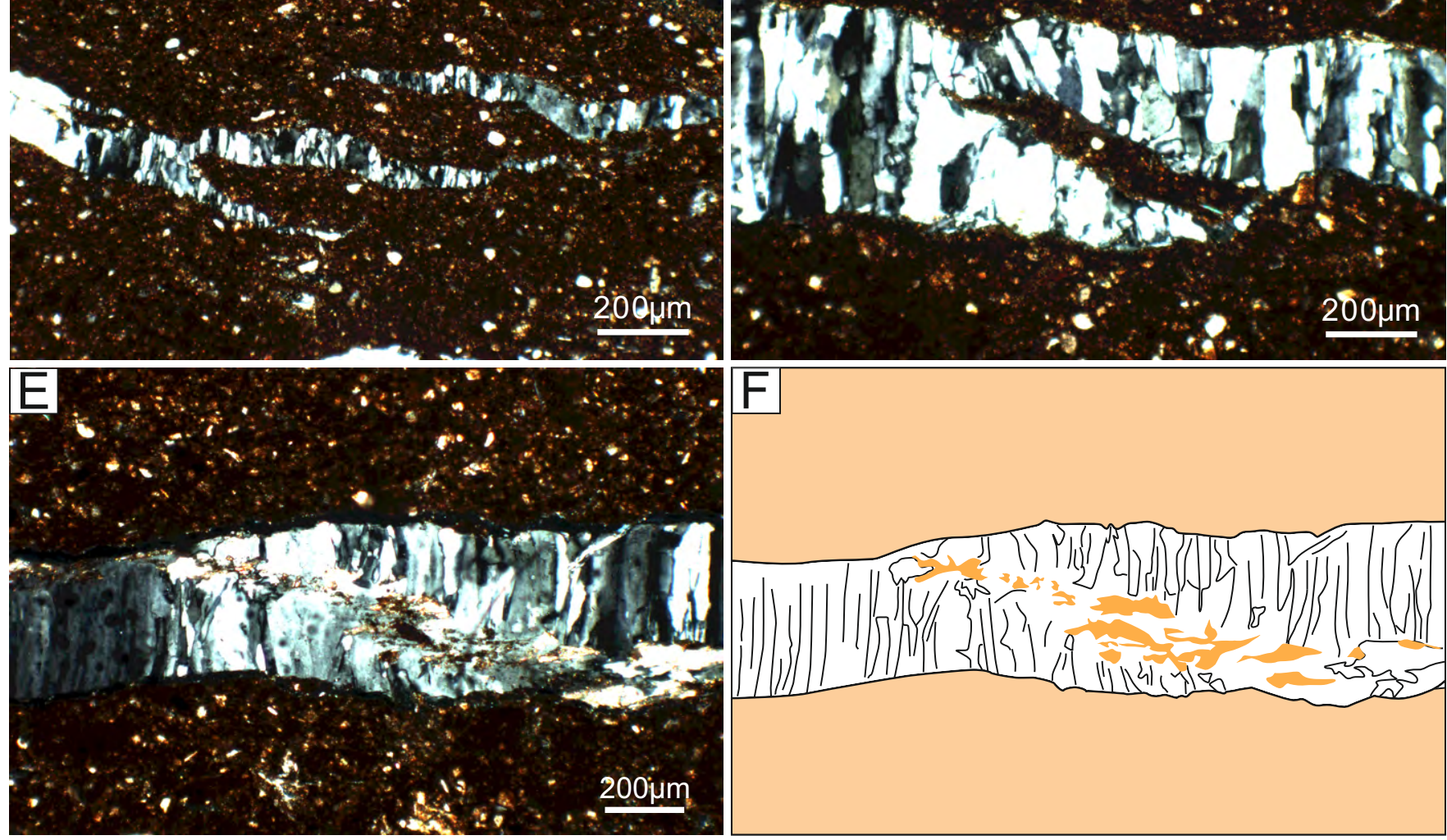

\section{$\mathrm{G}$} axu
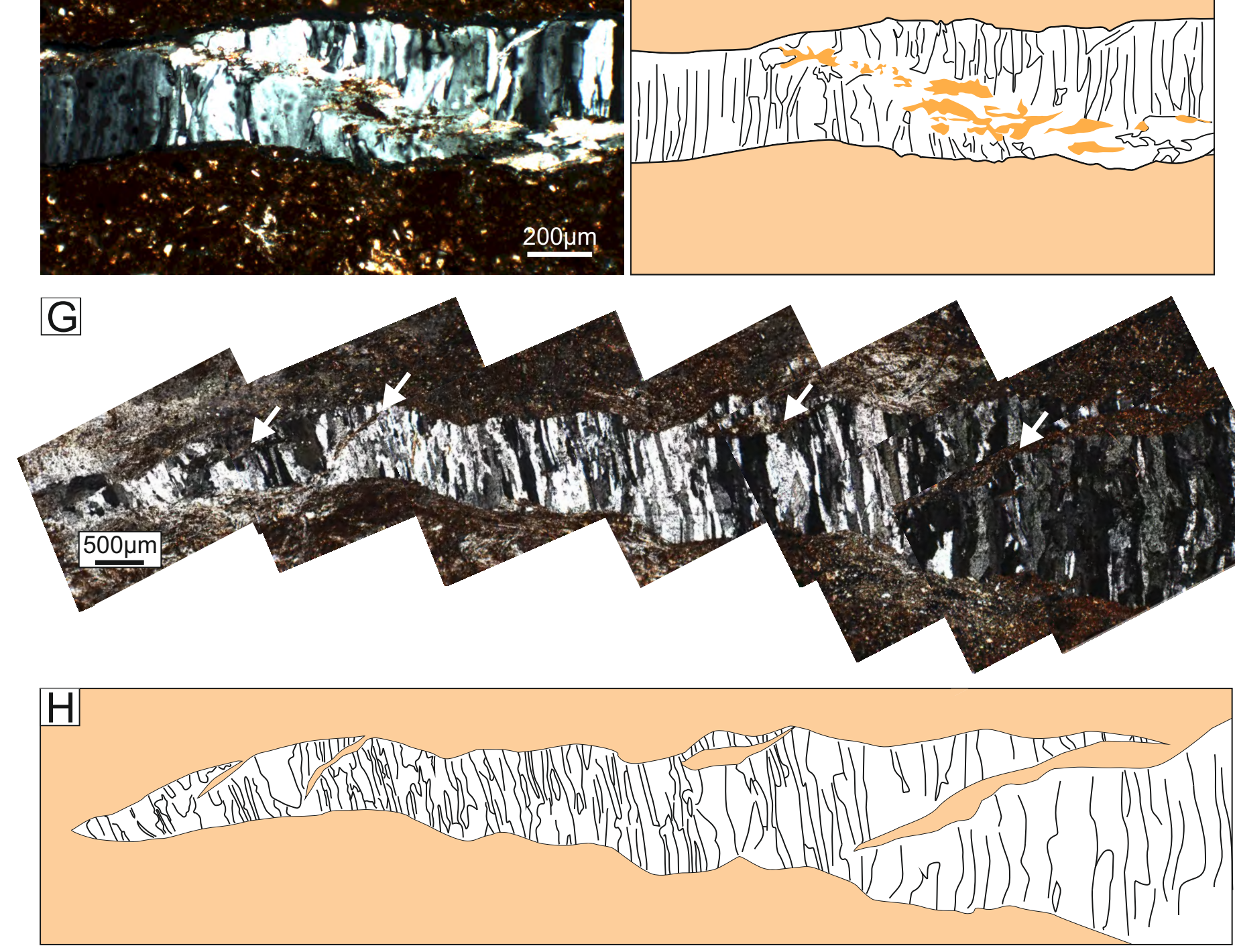

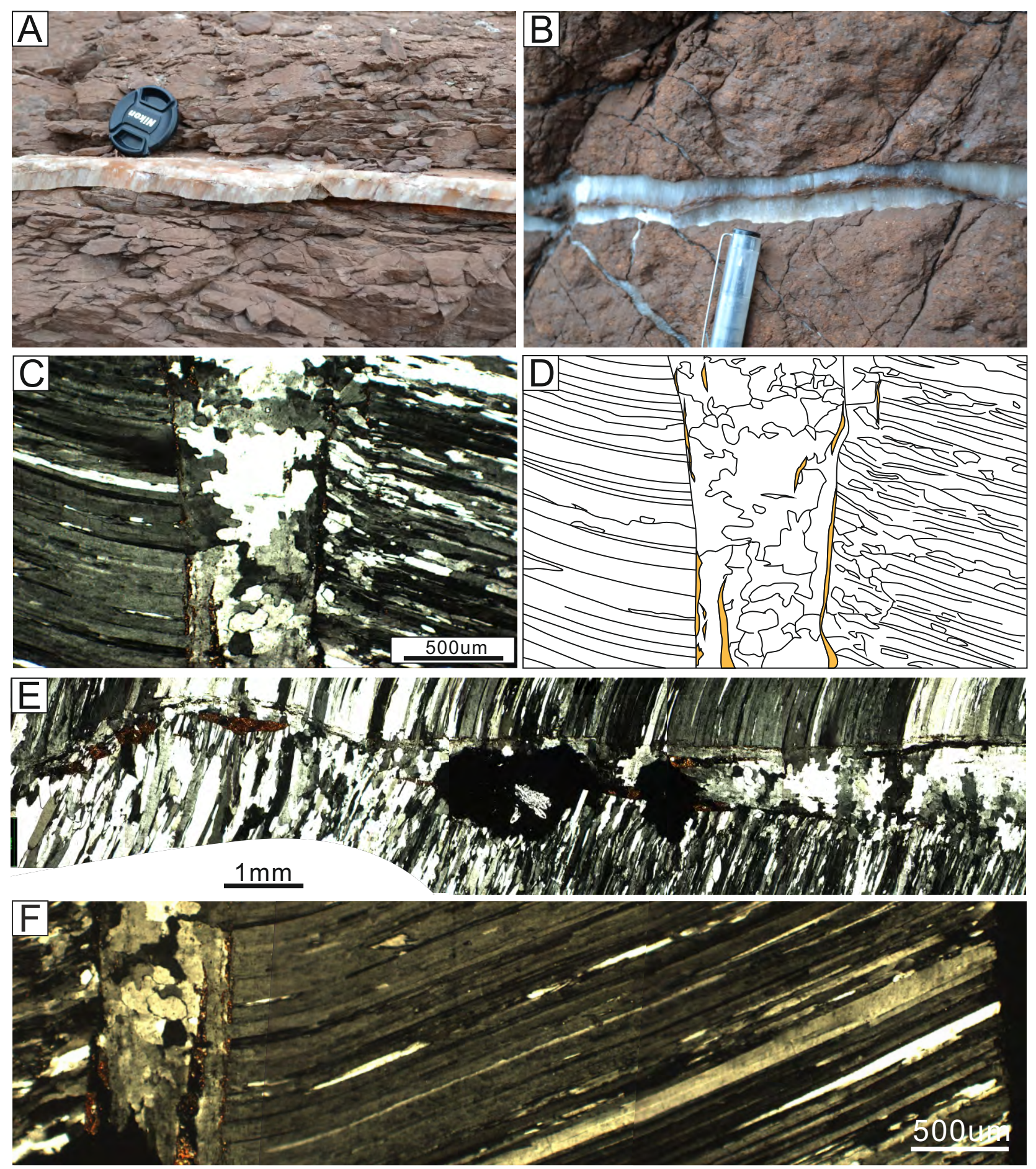

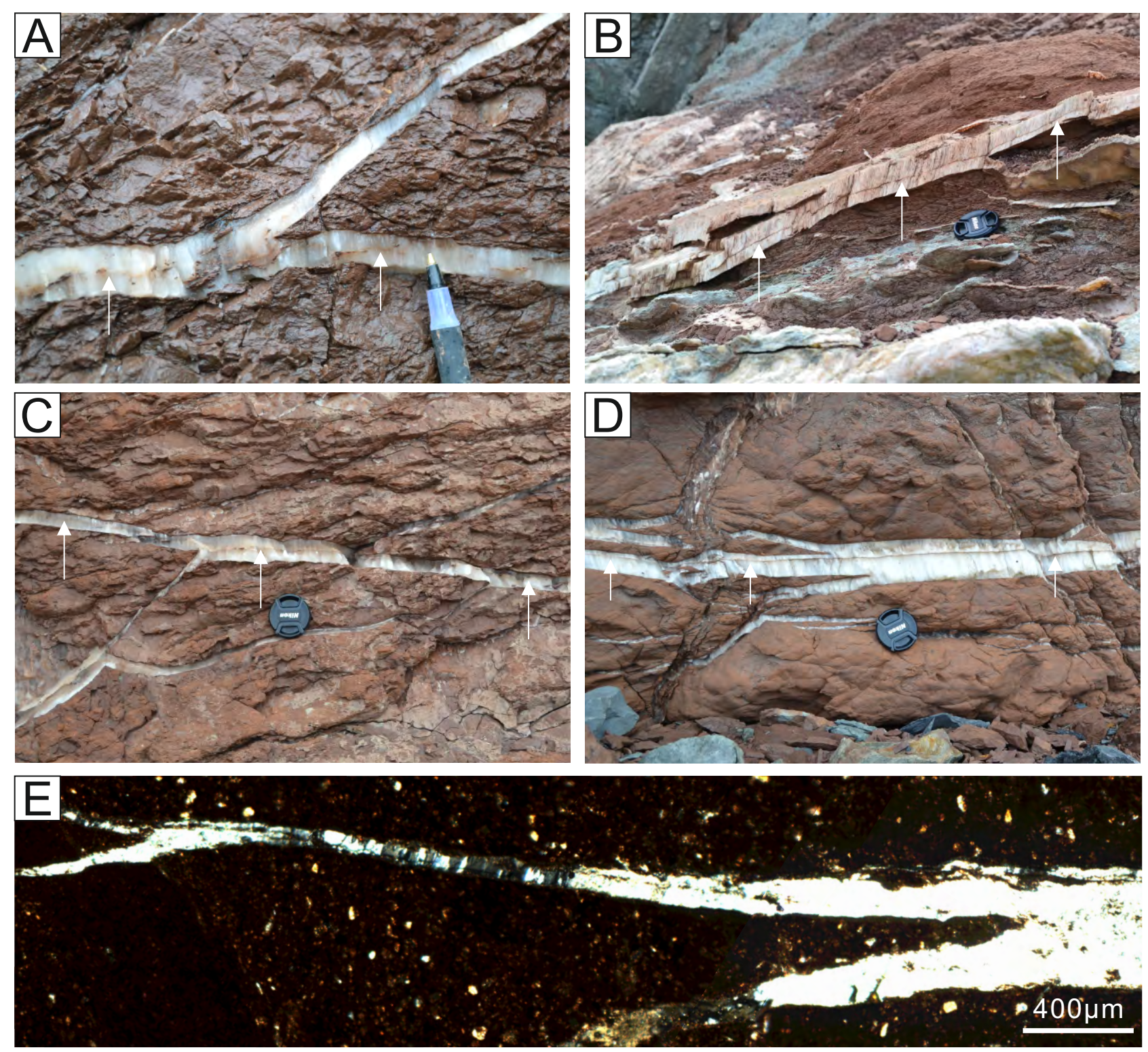

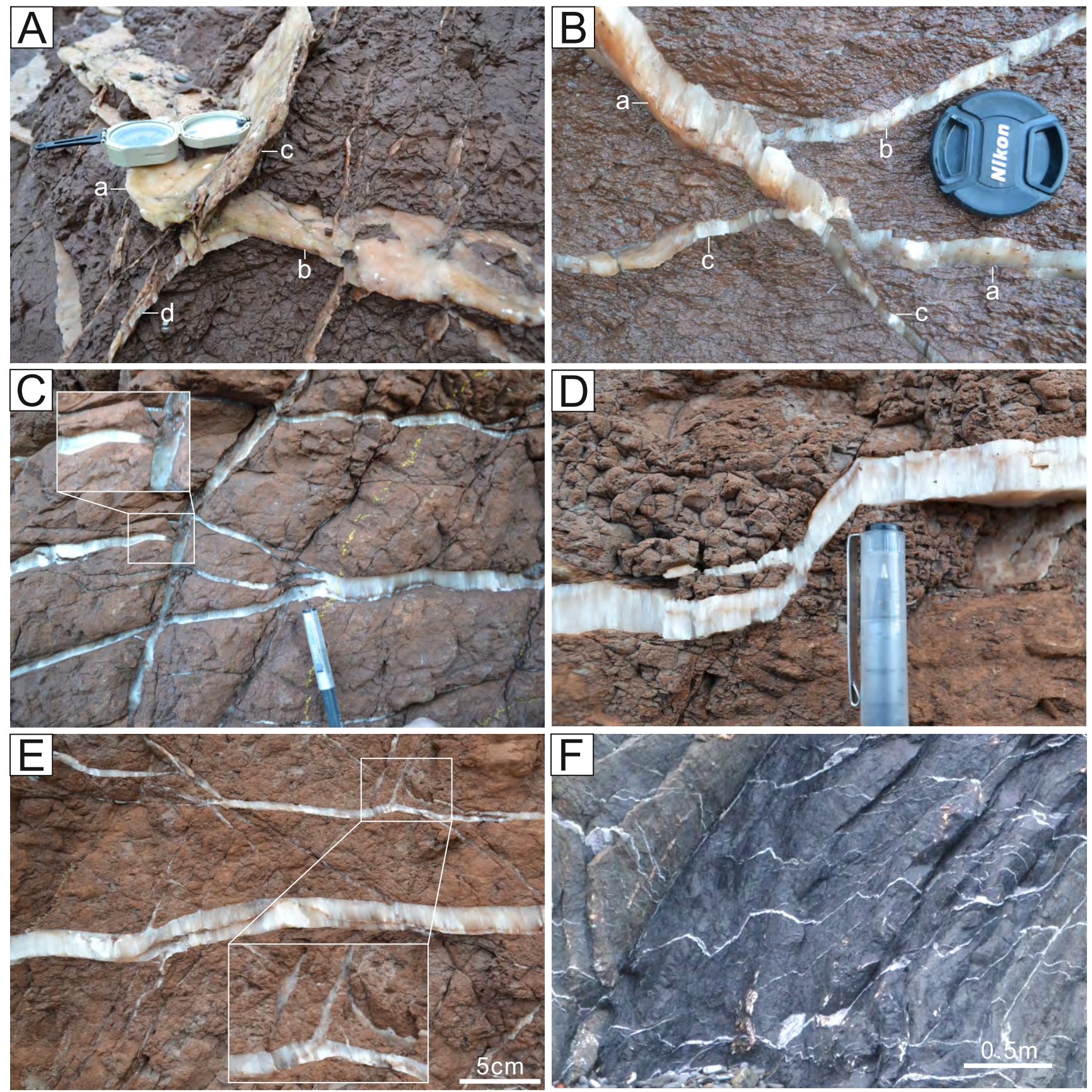


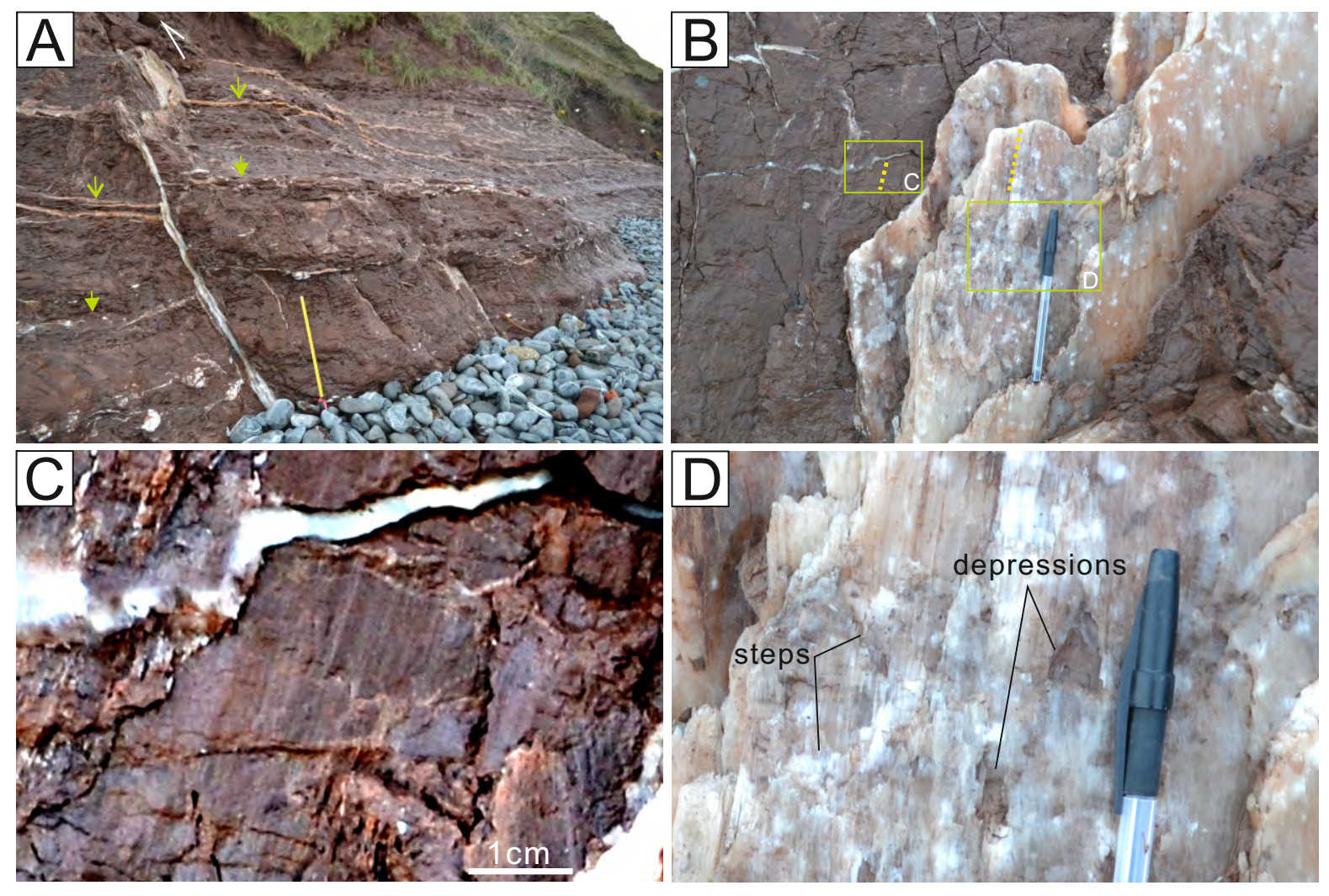



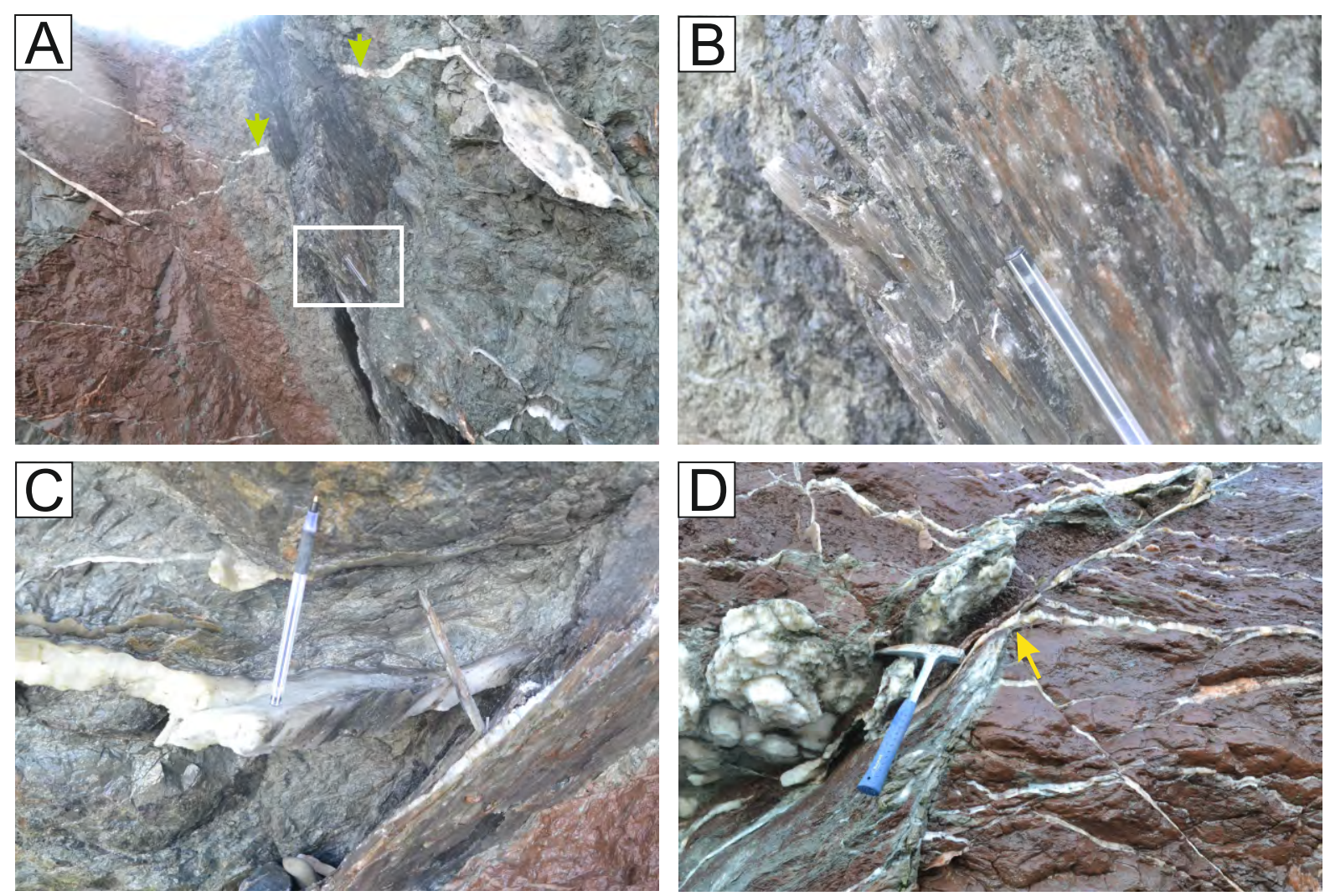


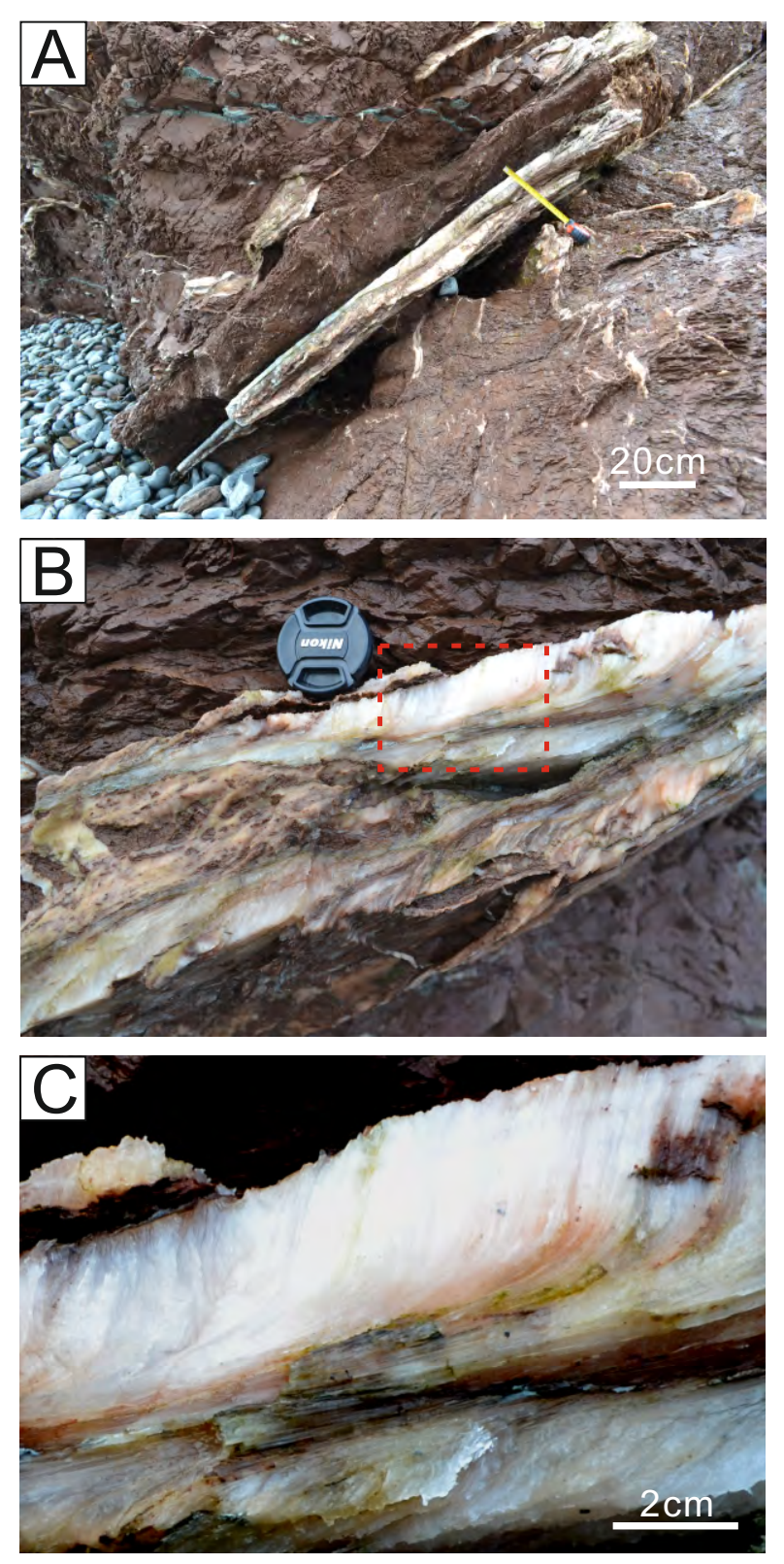



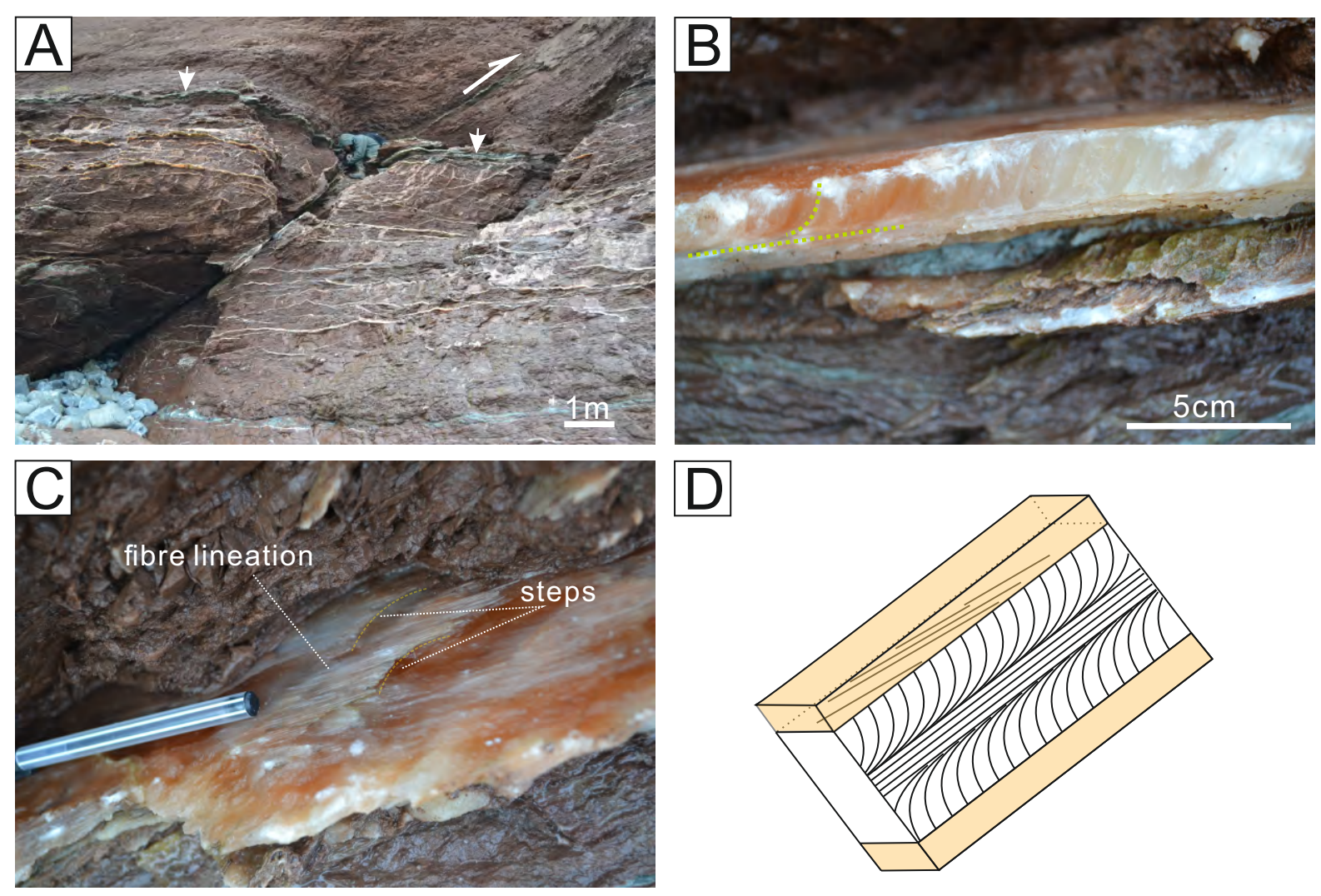


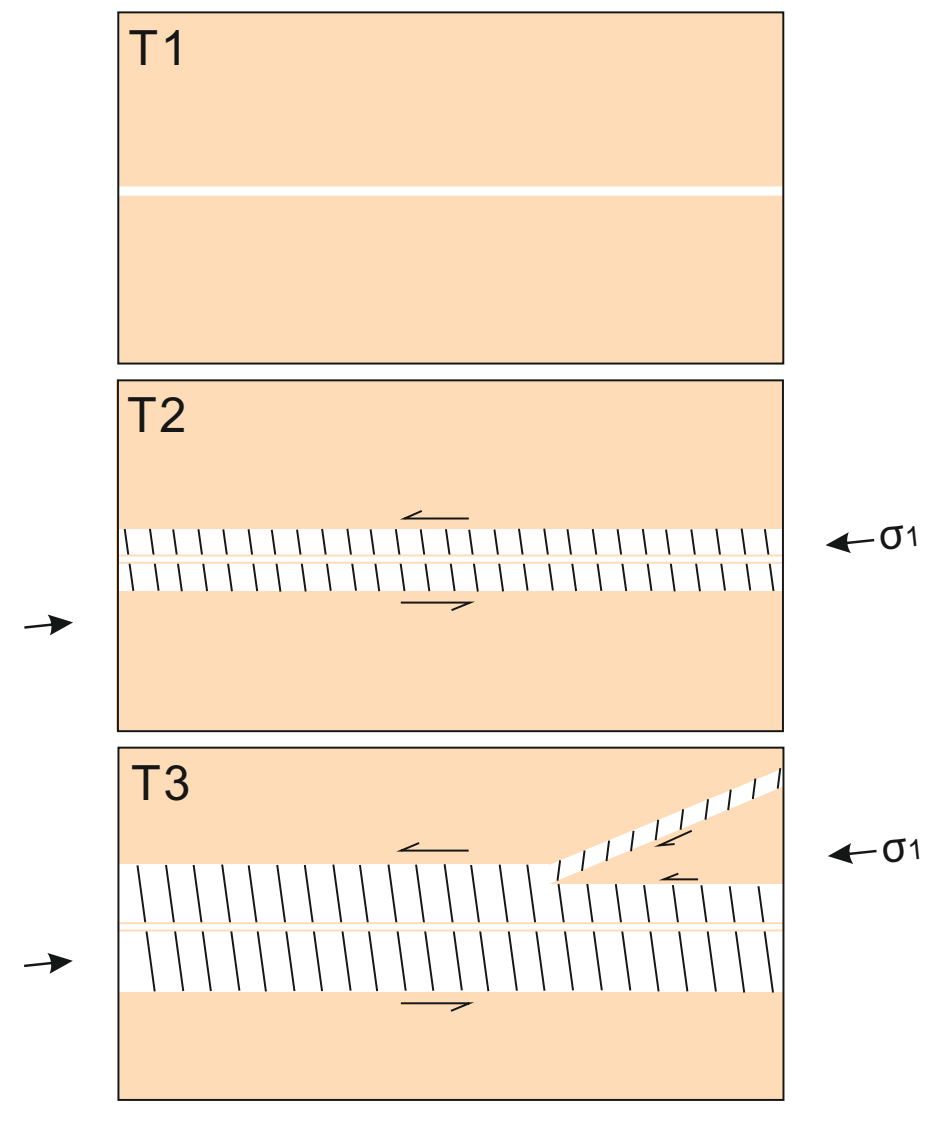


A.

Age (Ma)
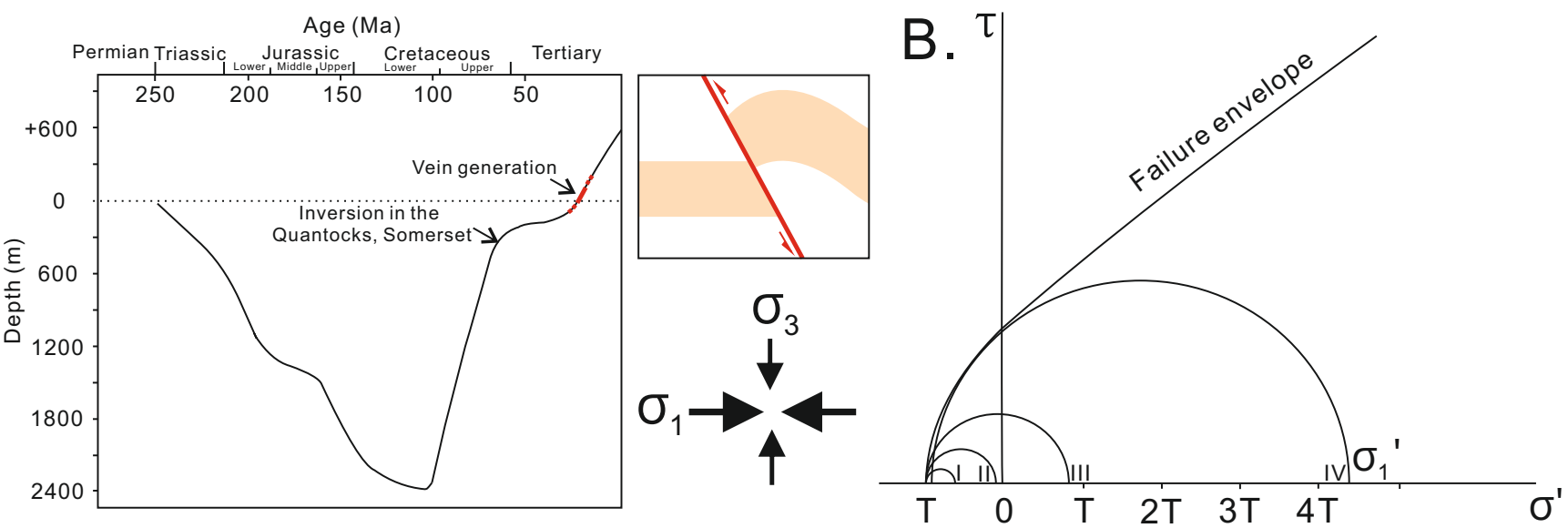

C.
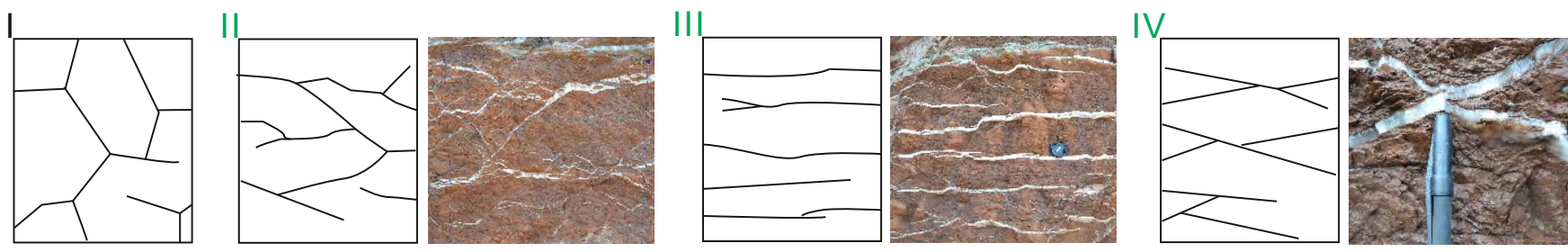
Table 1. Data for sandstone dykes of the Mercia Mudstone in study area. HGV, horizontal gypsum veins. IGV, inclined gypsum veins.

\begin{tabular}{|c|c|c|c|c|c|c|c|c|}
\hline \multirow[b]{2}{*}{ No. } & \multirow{2}{*}{$\begin{array}{c}\text { Dip } \\
\text { direction } \\
\left({ }^{\circ}\right)\end{array}$} & \multirow{2}{*}{$\begin{array}{c}\text { Dip } \\
\text { angle } \\
\left({ }^{\circ}\right)\end{array}$} & \multirow{2}{*}{$\begin{array}{l}\text { Trace } \\
\text { length } \\
(\mathrm{m})\end{array}$} & \multirow{2}{*}{$\begin{array}{l}\text { Aperture } \\
(\mathrm{cm})\end{array}$} & \multicolumn{3}{|c|}{ UTM Coordinates } & \multirow[b]{2}{*}{ Notes } \\
\hline & & & & & Northing & Easting & Zone & \\
\hline SD1 & 52 & 74 & 2.9 & 8.2 & 5670202 & 476345 & $30 \mathrm{U}$ & see Fig. 3B \\
\hline SD2 & 71 & 84 & 6.1 & 7.8 & 5670188 & 476263 & $30 \mathrm{U}$ & see Fig. $3 \mathrm{~A}$ \\
\hline SD3 & 52 & 75 & 2.8 & 6.6 & 5670184 & 476251 & $30 \mathrm{U}$ & curved shape, cross-cut by HGV \\
\hline SD4 & 61 & 70 & 0.6 & 8.2 & 5670184 & 476251 & $30 \mathrm{U}$ & curved shape, cross-cut by HGV \\
\hline SD5 & 99 & 41 & 0.8 & 1.2 & 5670176 & 476233 & $30 \mathrm{U}$ & cross-cut by HGV \\
\hline SD6 & 232 & 74 & 0.7 & 1.6 & 5670169 & 476202 & $30 \mathrm{U}$ & cross-cut by nodule-rooted $\mathrm{HGV}$ \\
\hline SD7 & 78 & 37 & 6.4 & 14.6 & 5670139 & 476061 & $30 \mathrm{U}$ & cross-cut by HGV and IGV \\
\hline SD8 & 122 & 50 & 2.8 & 16.8 & 5670119 & 476019 & $30 \mathrm{U}$ & see Fig. 3C \\
\hline SD9 & 56 & 59 & 4.0 & 22.5 & 5670114 & 476010 & $30 \mathrm{U}$ & cross-cut by HGV and IGV \\
\hline SD10 & 71 & 56 & 0.3 & 2.2 & 5670113 & 476007 & $30 \mathrm{U}$ & cross-cut by HGV \\
\hline SD11 & 68 & 64 & 0.6 & 2.0 & 5670113 & 476007 & $30 U$ & cross-cut by HGV \\
\hline SD12 & 70 & 60 & 0.4 & 0.8 & 5670113 & 476007 & $30 \mathrm{U}$ & cross-cut by HGV \\
\hline
\end{tabular}

